\title{
WestVirginiaUniversity
}

THE RESEARCH REPOSITORY @ WVU

Graduate Theses, Dissertations, and Problem Reports

2007

\section{Attitudes of the Thai press toward accepting federal money to report on HIV/AIDS}

Pattaraporn Niyamosoth

West Virginia University

Follow this and additional works at: https://researchrepository.wvu.edu/etd

\section{Recommended Citation}

Niyamosoth, Pattaraporn, "Attitudes of the Thai press toward accepting federal money to report on HIV/ AIDS" (2007). Graduate Theses, Dissertations, and Problem Reports. 4324.

https://researchrepository.wvu.edu/etd/4324

This Thesis is protected by copyright and/or related rights. It has been brought to you by the The Research Repository @ WVU with permission from the rights-holder(s). You are free to use this Thesis in any way that is permitted by the copyright and related rights legislation that applies to your use. For other uses you must obtain permission from the rights-holder(s) directly, unless additional rights are indicated by a Creative Commons license in the record and/ or on the work itself. This Thesis has been accepted for inclusion in WVU Graduate Theses, Dissertations, and Problem Reports collection by an authorized administrator of The Research Repository @ WVU. For more information, please contact researchrepository@mail.wvu.edu. 
Attitudes of the Thai Press toward Accepting Federal Money to Report on HIV/AIDS

Pattaraporn Niyamosoth

\author{
A Thesis submitted to the \\ Perley Isaac Reed School of Journalism \\ at West Virginia University \\ in Partial fulfillment of the requirements \\ for the degree of \\ Master of Science \\ in \\ Journalism
}

Diana Martinelli, Ph.D.,

George Esper, Ph.D.,

Ivan Pinnell, Ph.D.,

Carol Zwickel, Ph.D.

Perley Isaac Reed School of Journalism

Morgantown, 2007

Key Words: Attitudes of the Thai Press, Accepting Federal Money, HIV/AIDS Copyright 2007 Pattaraporn Niyamosoth 


\section{ABSTRACT \\ Attitudes of the Thai press toward accepting federal money to report on HIV/AIDS \\ Pattaraporn Niyamosoth}

This study focuses on the HIV/AIDS story in Thailand, specifically the attitudes of the Thai press toward accepting federal money to report on HIV/AIDS, and explores the differences between government media roles and independent media roles regarding this issue. Using Siebert's four theories of the press, Thai journalists' ideas regarding the current state of Thai media also were secured. A snowball sample was used. Six government media journalists, six independent media journalists, and six Ministry of Public Health of Thailand officials were studied via in-depth interviews. Most of the journalists did not believe that accepting federal money to report on HIV/AIDS would have a positive impact on either the HIV/AIDS issue or on the future of the Thai press. A combination of authoritarian and libertarian seems to be most embraced today in the Thai press system and one government journalist believes that social responsibility is most embraced today. 


\section{Acknowledgements}

I would love to thank the chair of the thesis committee, Dr. Diana Martinelli who helped me and taught me a variety of knowledge and perspectives of the field of journalism research. I'm truly grateful for her encouragement throughout this work, her precious suggestions for the research and the time she took to correct the thesis.

I specially thank Dr. George Esper for his efforts to clarify my research goals, helping me to organize the thesis and he was extremely willing to help me not only with the thesis, but also other classes.

I also thank Dr. Ivan Pinnell and Dr. Carol Zwickel for their support and thoughtful advice which made this study valuable.

I thank the Thai journalists and the Ministry of Public Health officials of Thailand who allowed me to interview, for their time and dedicated help in answering the in-depth interviews and giving me their perceptions. Without their help, this thesis would have been impossible.

Finally, I wish to express my deepest gratitude, gratefulness, love to my mom, dad, Dr. Surat Lek-Utai for loving me unconditionally, giving me the wonderful life, being the invaluable fortunes deep in my heart. Without their constant encouragement and patience this would not have been possible. 
TABLE OF CONTENTS

Page

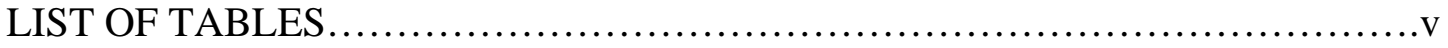

Chapter

1. INTRODUCTION ....................................................

Statement of the Problem and Justification.............................. 5

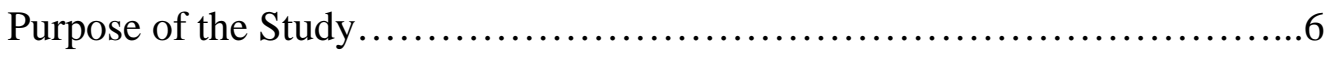

2. LITERATURE REVIEW............................................. 7

Four Theories of the Press............................................

Thailand System.................................................. 10

Thailand and AIDS......................................................

Media and AIDS ...................................................... 17

Research Questions....................................................39

3. METHOD........................................................40

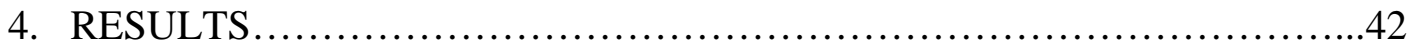

5. DISCUSSION, LIMITATIONS AND FUTURE STUDIES..................58

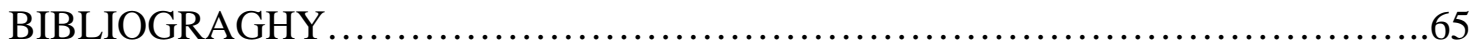

APPENDIX A: Interview Questions........................................69

APPENDIX B: Thailand Media..............................................71 


\section{LIST OF TABLES}

Table

Page

1. The Current Situation..................................................33

2. Summarizing the Journalists Interviewed...............................56 


\section{CHAPTER 1}

\section{INTRODUCTION}

The first case of AIDS $^{1}$ was reported in Thailand in 1984, and it is believed that prevalent transmission began in the late 1980s. In 1988-1989, in the first major wave of the epidemic, $\mathrm{HIV}^{2}$ exploded among injecting drug-users, rising from almost no known cases to $40 \%$ in a single year (Phanuphak, 1995). At almost the same time, a second wave of infection spread among prostitutes. In 1989, it was found that $44 \%$ of prostitutes in Chiang Mai province, in the northern areas of Thailand, were infected with HIV. The increasing infection level among prostitutes resulted in a rising epidemic in the male clients of prostitutes, their wives, their children and their girlfriends (p. 195-199).

A few years later, prostitutes, gay men, injecting drug users and tourists were more influenced than other groups. Although the government took some basic measures to handle the issue, an epidemic was not yet clear. Most of these measures were aimed at high-risk groups, as the government believed that there was inadequate reason to carry out prevention campaigns among the general public (Porapakkham \& Pramarnpol, 1995).

Meanwhile, public awareness of the issue was rising. Cha-on Suesom, a factory laborer who became infected with HIV by a blood transfusion, agreed to allow his story to be broadcasted in 1987, and his story was widely publicized through the media. He became well known after appearing on TV shows and in national newspapers, allowing the public to understand the human side of the epidemic. Cha-on and his wife had both been fired from their jobs as a result of his HIV-positive status, and the injustice of this

\footnotetext{
${ }^{1}$ AIDS: Acquired Immune Deficiency Syndrome

${ }^{2}$ HIV: Human Immunodeficiency Virus
} 
situation helped to increase public sympathy for people living with HIV (Porapakkham \& Pramarnpol, 1995).

In Thailand, few laws exist to protect and preserve the daily life of those infected with HIV or AIDS. The negative social attitudes towards those who have HIV or AIDS means that careless reporting could have a serious negative impact on the individual or individuals concerned. Inappropriate media reporting can also perpetuate myths and stereotypes and so contribute to stigma and discrimination.

On April 5, 2006, Thai journalists agreed on a united stance against media stigmatization. Members of the Thai Journalists Association (TJA), Thai Broadcast Journalists Association (TBJA), Press Council of Thailand, Economic Journalists Association, and media scholars adopted a resolution calling for press freedom in presenting news and opinions, as guaranteed by Article 39 of the Thai Constitution. This recent development in mass media communications policy in Thailand has the potential to conflict with circumstances where the Thai government is funding specific stories in specific ways about HIV and AIDS.

In 1932, Thailand, a culture of authoritarianism and king-worship, changed to a parliamentary democracy, still the government retained a fairly strong hand in the way journalists reported the news as well as what they were able to report. These recently granted freedoms of the press have created many internal issues with journalistic ethics. A freer press, combined with a governmental lack of strict policies on discrimination of persons infected with HIV/AIDS, necessitates the need for specific ethical guidelines for reporting on HIV and AIDS. 
Censorship in Thailand is forced to protect national security, preserve public order, maintain the rights of others, preserve public morals, and avoid criticism of the royal family. However, criticism of the king is forbidden by the Constitution.

Google's video sharing site YouTube has been blocked for several days in April 2007 by the government of Thailand after as a minimum 3 videos insulting King Bhumibol Adulyadej, King of Thailand, were uploaded to the website.

A Swiss man, Oliver Jufer, convicted of lèse-majesté for defacing posters of Thailand's king and queen, he was sentenced to 10 years in prison on December 2006, the first time in many years that a foreigner faced jail for the felony (International Herald Tribune, 2007).

This shows that the power of censorship and the king in Thailand have so much influence on media and the country even though Thailand has a democracy system.

But should these guidelines be created by a coalition of the press or should the press look towards, and possibly force, government's hand to structure a policy, thereby possibly relinquishing some of the new-found freedom the Thai press is striving for? For example, political pressure from human rights activists has forced the Thai Government to consider new laws to protect its citizens from discrimination due to HIV/AIDS infections. This, however, is occurring at the same time the Thai media are gaining newfound independence in their ability to disseminate and report the news the way they want, including the reporting of AIDS infection. These ongoing developments, on both sides, will necessitate strict guidelines in the ethics of the Thai media when dealing with issues such as HIV/AIDS. 
Several problems can, and potentially will, arise from these developments - a struggle for independent free writing from the press, and a push for privacy from HIV/AIDS advocacy groups. This thesis project will explore the background of this issue and answer questions to help understand the issue from both government and media perspectives. The results will be shared with the authors’ Bureau of Public Health.

There are few countries in the world where public guideline has been successful in preventing the spread of HIV/AIDS on a nationwide level, but Thailand is an omission. A massive program to control HIV has diminished visits to commercial sex workers by half, increased condom usage, reduced the prevalence of STIs ${ }^{3}$ significantly, and achieved large reductions in new HIV infections (UNDP, 2004).

Besides, Thailand is a reminder that accomplishment can be relative. Its well funded, politically supported and widespread prevention programs have saved millions of people, dropping the number of new HIV infections from 143,000 in 1991 to 19,000 in 2003 (UNPD, 2004). However, more than one-in-100 adults Thailand of 65 million people is infected with HIV/AIDS has turned out to be a leading cause of death (UNAIDS/WHO, 2006).

Unless past efforts are continued and new sources of infection are addressed, the striking successes made in directing the pandemic could now be put at risk. Factors such as an increase in unsafe sexual behavior and a growing number of STI cases have led to concerns that Thailand could confront a reappearance of HIV/AIDS in the future. The government has significantly reduced funding for AIDS prevention programs, and there are signs that public knowledge is waning. Satisfaction among both the government and

\footnotetext{
${ }^{3}$ STIs : Sexually Transmitted Infections
} 
the public poses a true threat to the fight against AIDS in Thailand (International Herald Tribune, 2005).

\section{Statement of the Problem and Justification}

Thai journalists are entering into a new era of freedom. This era, however, is also bringing with it the Thai version of yellow journalism, invasion of privacy, and the sensationalism of news without regard for the human experience. At a time when the Thai government is considering enacting new laws and regulations to protect its citizens infected with HIV/AIDS from discrimination and harassment, the Thai media are also exercising new-found freedoms in the ability to report self-evaluated news stories without government intervention. Soon, and inevitably, a conflict will arise between the Thai media outlets and the Thai Government on the issue of AIDS awareness.

The Thai Government is failing despondently with its federal PR campaign to spread the knowledge of HIV/AIDS through its population. By 2003, government spending on prevention had fallen to little more than one-third of what it had been six years earlier. "There is still an opportunity to prevent resurgence, to nip it in the bud, but to do that the government has to focus on prevention, and that isn't happening,” the regional program adviser in Bangkok for the UN agency dealing with AIDS stated.

At a time when the AIDS epidemic is turning Thailand into a hot zone where, if projected numbers come true, one in five of every adults will have AIDS by 2025, makes the struggle among the government and its potential story placements about HIV/AIDS, human rights activists and the press's desire for freedom an important issue. 


\section{Purpose of the Study}

The purposes of this thesis research have included the following:

To study the HIV/AIDS story in Thailand

$>$ To study attitudes of the Thai press toward accepting federal money to report on HIV/AIDS

$>$ To study the differences between the government media role and independent media role

To study the four theories of the press and the Thailand press system 


\section{CHAPTER 2}

\section{LITERATURE REVIEW}

In the book Politics and the Press in Thailand: Media Machinations, (Duncan, 2002) discusses the role of the Thai press as a watchdog group. The various limitations on the press are detailed at length with a point-counterpoint style of writing. Duncan's overall perception is that over the past several decades, the overall thrust of the Thai media has made a gradual transition from a servant of the public to a watchdog entity which helps to protect its citizens from political corruption. Duncan contends that one version of the watchdog theory sees the press as a surrogate opposition, helping to compensate for the deficiencies and shortcomings of political parties and other civil society groups. Citing numerous examples, Duncan alludes to the fact that the Thai press may not simply be a barking watchdog, but also on occasion a biting watchdog, which acts forcefully to challenge numerous governmental abuses and to promote the public interest. With several forward looking thoughts and conjectures, Duncan believes that the Thai media may become the sole leading force for progressive political change or “democratization” of the Thailand political landscape.

\section{Four Theories of the Press}

In the book Four theories of the press: The authoritarian, libertarian, social responsibility and soviet communist concepts of what the press should be and do, Siebert, Peterson, and Schramm (1963) discuss the four theories of the press as following:

\section{The Authoritarian Theory}

The Authoritarian theory needs governmental control of the mass media. This theory is easy to recognize in pre-democratic societies, where the government consists of 
a very limited and small ruling-class. The media in an authoritarian system don't permit broadcasting or publishing anything that can demoralize the established authority and any offense to the existing political values is evaded. The authoritarian government may punish anyone who questions the state's principles.

The basic assumption of the authoritarian theory is that the government is perfect. Accordingly, media professionals are not allowed to have any freedom within the media organization. Also, media from overseas are subordinate to the established authority. All imported media products are controlled by the state.

There might be an unavoidable parallel between the authoritarian media structure and a totalitarian society. It is true for the most part, but a government may force an authoritarian profile without being openly totalitarian. Albania is now a country that comes close to having this type of media system.

\section{The Libertarian Theory}

The Libertarian theory is opposite of the Authoritarian theory. It is also called the free press theory, as the libertarian view depends on the idea that individuals should be free to print whatever they like. Its history dates back to the 17th century's thinker John Milton, who emphasized that human beings unavoidably choose the best ideas and values. In the libertarian structure, attacks on the government's policies are completely encouraged and accepted. Furthermore, there should be no limitations on the import or export of media messages across the national frontiers. Besides, journalists must have full independence within the media organization. The U.S. is an example of a country that comes close to the libertarian system. 


\section{The Social Responsibility Theory}

In the late forties, an American initiative introduced the social responsibility theory. Realizing that the market had not succeeded to complete the promise that press freedom would disclose the truth, The Commission on Freedom of the Press offered a model in which the media had certain obligations to society. These obligations were stated in the words “informativeness, truth, accuracy, objectivity, and balance.” Siebert states that the goal of the social responsibility structure is that media as a whole is pluralized, representing "a reflection of the diversity of society as well as access to various points of view.” (Siebert, Theodore, \& Wilbur, 1963).

Moreover, the Social Responsibility theory is to offer a different mass media to minority groups. The journalists are accountable to audiences as well as to the government. Nowadays, most media systems in Western Europe countries come close to the social responsibility theory.

\section{The Soviet Communist Theory}

The media institutions in the Soviet communist system were to serve the interests of the working class and were not intended to be confidentially owned. The Soviet Communist theory appears to be the same as the authoritarian theory in that both theories admit the government as superior to the media organizations. However, there is a major difference between the two theories that needs to be clarified. The media in the Soviet communist theory are anticipated to be self-regulatory with regard to the content of their messages. Also, the Soviet theory is different from the authoritarian theory in that the media organizations have a certain responsibility to meet the needs of their audiences. 
Still, the fundamental standard is to offer a full and objective view of the world according to Marxist-Leninist ideology.

Beginning in the mid-eighties and continuing after the fall of the Soviet Union, Russia has presented a mass media model closer to the social responsibility theory. The example of the Soviet media theory is how the media function in China, where television, radio, and newspapers are directed by the communist government.

\section{Thailand System}

Censorship in Thailand has a long history. Before Thailand became a parliamentary democracy in 1932, the King had total governmental control. The King would enact laws and directly control the media with both the government and the military, along with economic pressure. To this day, Thailand has some rather strict censorship laws. Numerous websites are blocked from public access. The government states the top reasons for this restriction are pornography, national security, and criticisms of the King, the Government or the military.

Thailand is a combination of the authoritarian theory and the libertarian theory. Because Thailand has a king and a kind of a pre-democratic society, the authoritarian theory fits with the censorship and government control. The libertarian theory also fits because of the fact that there are some freedoms of the press and not everything is controlled. It is not the social responsibility theory because the government will not let it be, but Thai journalists seem to want the social responsibility theory to be a working model.

The detailed history of actual and attempted governmental censorship of the Thai media outlets reflects directly and generally on the issue stated within the problem 
statement of this thesis while the Thai Government has a long history of censorship of the media, and while the Ministry of Public Health has created several ad campaigns for HIV/AIDS awareness, no branch of the Thai Government has ever funded the press to report on a specific story. The Ministry of Public Health has been credited for the stunning success of its previous HIV/AIDS awareness campaigns. The Ministry has shown a tremendous commitment to providing comprehensive care and support to Thai citizens infected with HIV/AIDS, but it is only recently that it has been able to provide a specific treatment of anti-retroviral drugs to large numbers of people with symptomatic HIV. This is due to an affordable domestically-produced triple-drug combination, called GPO-vir (stavudine + lamivudine + nevirapine), which costs about \$30US per month. This has allowed the Ministry of Public Health to begin an advertising campaign of never before seen proportions to inform the public that the triple-drug anti-retroviral should be the primary and standard care.

While Thailand is recognized as a leader in information and prevention of the spread of HIV/AIDS, certain groups such as AVERT (www.avert.org), an international AIDS charity, fear that success can be relative to the amount of funding. AVERT supports such programs as that of cabinet member Mechai Viravaidya, a well-known Thai AIDS activist and politician who developed a program where anti-AIDS messages aired every hour on the country's 488 radio stations and six television networks, and every school was required to teach AIDS education classes. Viravaidya's programs were based on government purchasing of air time on the Thai free-press, and by government regulation of the state owned media outlets. Ministry of Public Health records indicate 
they were spending in excess of $\$ 80$ million US annually on Viravidya’s media campaign.

With a tremendous distrust of the Thai Government (based on past media censorship), it would be difficult for the Thai Media to accept money from the government, even when the outcome may be for a greater good.

Journalists know they rely on a bond of public trust to do their job well and preserve media freedom, which is based on the constitutional right of free expression. Without media freedom, newspapers would be nothing but ink-stained pages, and broadcast journalism would all be the same and make a mockery of the people's right to access factual information and a free exchange of views.

In an effort to gain factual background information for this thesis, I have collected various statements of proof of both governmental interference with the Thai collective media, and abuses of ethics by the Thai Media:

\section{Abuse of State Power, Interfering with the Media}

In 2001, the army-run Channel 5 blocked the Joh Jai (Frankly Speaking) and Thee Nee Prathet Thai (This is Thailand) programs, which would have aired interviews with a Thai female monk, Dhammananda Samaneri, formerly Chatsumarn Kbilsingh, a feminist and Buddhist scholar ordained in Sri Lanka. This is in violation of Article 39 of the constitution, which ensures freedom of expression and of Article 40 regarding the broadcasting media reform.

> The army's June 29, 2001 order for its radio and television stations to air constructive news about the prime minister and cabinet ministers and to publicize 
government policies and measures. This is in violation of Articles 39 and 41 of the constitution, which guarantee freedom of the press.

In 2001, the cabinet secretariat told ministers to use the Public Relations Department's television channel 11 to publicize the government's performance, a misuse of state-run media.

On August 2, 2001, Special Branch police sent letters to warn the Thai Rath and Krungthep Thurakit newspapers not to print the reports on the share concealment case against Prime Minister Thaksin Shinawatra. Their reports might have had an impact because Thai people might think that Prime Minister Thaksin's money was from corruption.

\section{Threats and Physical Abuses against the Press}

$>$ Thawee Keeratirangsan, a Daily News reporter for the Chum Pae city, was assaulted on February 3, 2001. The motive was believed to have resulted from his reporting on the demonstration of Chum Pae municipality employees demanding a job extension.

A bodyguard of Defense Minister Chavalit Yongchaiyudh pushed and threatened a reporter at the Transport and Communications Ministry on March 16, 2001 while the reporter was interviewing Chavalit.

Withayut Saengsopit, a radio host in Surat Thani, was murdered on April 11, 2001 after revealing allegations of corruption in the local municipal council. 
Kitti Maneechote, Thai Rath's reporter for Saraburi, was attacked on April 10, 2001. The attack was believed to have been motivated by his reporting on illegal transport business.

Kaset Phuengpak, Thai Rath's reporter for Aang Thong, was shot dead on May 2, 2001. Police suspected his reports revealing the illegal business of a provincial mafia ring as a motive behind the killing.

$>$ Thanomsak Noonoum, Matichon's reporter for Trang, was assaulted by a group of five youngsters armed with weapons while he was driving. Police suspected his news scoops were revealing the thriving sex trade of women under the age of 18.

Veenus Eiamsa-ard, Thai Rath's reporter for Ubon Ratchathani province, was threatened with an M-67 grenade placed in front of her office on December 19, 2001. Police suspected her report exposing the vested interests of uniformed personnel was a motive.

\section{Abuses of Media Ethics and Professionalism}

A stringer for the newspapers Thai Rath and Daily News in Prathum Thani province was involved in a move to overturn the criminal court case involving a senator who was accused of molesting a girl under the age of 15. The newspapers later fired this stringer.

$>$ The Press Council of Thailand issued a statement dated September 27, 2001, urging newspapers to exercise caution in printing pictures or cartoons in the aftermath of the September 11, 2001 terrorist attacks in the United States, which were deemed to cause national disunity. 
The Press Council of Thailand issued a statement dated November 16, 2001, urging newspapers and other printing documents to tighten their ethics codes and professional standards in response to a complaint that provincial reporters of certain local dailies have misused their profession for business interests.

The Press Council of Thailand issued a statement dated December 10, 2001 urging newspapers to tighten management procedures, recruitment criteria and penalty codes for provincial reporters to deter to future abuses of professional media ethics.

The Press Council of Thailand issued a statement dated December 10, 2001, urging reporters and news organizations to refrain from taking valuable gifts from government officials or politicians during New Year celebrations and for government officials and politicians to abstain from giving precious gifts to reporters and news organizations. Offenders in media circles are subject to ethical scrutiny.

\section{Code of Conduct for Members of the Thai Journalists Association}

Encourage and preserve freedom of expression and news reporting.

$>$ Offer only precise news information and arrange to correct those found to be mistaken.

Be truthful and respectful in discharging function, especially in obtaining documents, photographs and other informative materials useful for news reports.

Respect the privacy of news sources.

Present duties for the most benefit of the public and restrain from seeking selfgain and from being an instrument of any group of people.

Abstain from any act that may be harmful to the profession's image and integrity. 


\section{Code of Ethics for Reporters by the Executive Board of the Press Council of Thailand}

Journalists must not violate the integrity of the institution of the independent media and the profession in which he or she works.

Journalists must not abuse his/her position or make use of the profession in such ways that would result in obtaining favours.

$>$ Journalists are prohibited from taking bribes or accepting valuable gifts or favours from sources because it could influence directly or indirectly the content of news reporting. Item 23: Journalists must not accept any privilege or position that will influence their professional performance in disseminating correct and comprehensive information.

$>$ When presenting a news report, newspapers must take into consideration the welfare and the benefit of the general public.

Newspapers must obtain information in a dignified manner.

Newspapers must not have a hidden motive when expressing opinion or news analysis.

Newspapers must take into consideration the rights of an individual and balance it with the public's right to know.

Newspapers must not allow paid advertisements to violate the established code of ethics of their industry and take into consideration the customs and values of the Kingdom. 
Newspapers must avoid paid advertisements that knowingly distribute false information to the public. Newspapers must not use profanity and avoid obscene gestures in their reporting.

"When you are working to combat a disastrous and growing emergency, you should use every tool at your disposal. HIV/AIDS is the worst epidemic humanity has ever faced. It has spread further, faster and with more catastrophic long-term effects than any other disease. Its impact has become a devastating obstacle to development. Broadcast media have tremendous reach and influence, particularly with young people, who represent the future and who are the key to any successful fight against HIV/AIDS. We must seek to engage these powerful organizations as full partners in the fight to halt HIV/AIDS through awareness, prevention, and education.",

\section{- Kofi Annan, United Nations Secretary-General}

\section{Thailand and AIDS}

A recent study (AIDSCAP, 2005) was conducted by researchers from the ASEAN Institute at Thailand's Mahidol University and a U.S. consultant. This study details the development of Thai governmental HIV/AIDS policies and programs under five different prime ministers during the years 1984 to 1994 . Most studies prior to this one had centered around statistics and historical numbers to make forward looking projections; the AIDSCAP study is instead based on interviews with many of the individuals responsible for shaping AIDS policy in Thailand during the past 10 years. Twenty key informants from government, universities and nongovernmental organizations (NGOs) were 
interviewed and assured that their comments would not be identified by name so that they could speak frankly.

The results of these interviews show how three distinct periods of dealing with the internal HIV/AIDS crisis took shape. The following three detailed periods are summarized from The Evolution of HIV/AIDS Policy in Thailand 1984-1994 (Henry, 2005).

\section{Business as Usual}

The first publicly released case of AIDS in Thailand was reported in 1984 during the rule of a former army commander, General Prem Tinsulanonda, appointed as the premier in 1982. General Tinsulanonda and his business-oriented cabinet were strongly opposed to the releasing of information about a new disease that they thought would disrupt their plans of boosting the failing Thailand economy (Henry, 2005).

In 1987, the reporting of AIDS among the Thai population was frowned upon during a tourism campaign called "Visit Thailand Year.” This was a multimillion-dollar campaign to boost international tourism. Specifically in contrast to the early efforts in quelling the blooming AIDS epidemic, some informants charged that efforts to promote sex tourism were actually intensified by certain corrupt segments of the Thai government during this period (Henry, 2005).

The Thai government took, and made public, the stance that most of the AIDS cases were from Thais who had been infected abroad. This allowed the government to blatantly dismiss HIV/AIDS as a "foreigners' problem." Reports of AIDS among homosexuals, prostitutes and drug users only reinforced the false and government 
promoted belief that the disease was not a concern for the majority of Thai citizens (Henry, 2005).

The AIDSCAP report notes, “The disease was blamed on foreigners, intravenous drug users and homosexuals, and activities carried out by the government were targeted toward these communities,” “Once AIDS became associated with these marginalized groups, it was very difficult to alter that perception” (Henry, 2005, p. 5).

\section{Toward Acceptance}

In June of 1989, a report was leaked to the press by government epidemiologists who disregarded the orders of their superiors, risking both their jobs and their freedom. The report stated that 44 percent of all prostitutes in the brothels of the northern city of Chiang Mai were HIV-positive. The news spread throughout Thailand, much to the chagrin of the government, and had a far-reaching impact on the sexual behavior of Thai men.

\section{Government Activism}

The wealth of data from private sources, against the wishes of the previous government, became available in 1989 and 1990 and paved the way for an extraordinary period of forced government activism against HIV/AIDS under the interim government of Anand Panyarachun. Appointed prime minister after a military coup d'etat in February 1991, Anand selected a cabinet of technocratic activists, including a prominent AIDS activist who was put in charge of the AIDS agenda. Unlike previous administrations, Anand's government was willing to release the reports and HIV/AIDS statistics. They also worked closely with the media to raise awareness of the epidemic and the threat it posed to Thai society. Several acts of discriminatory AIDS legislation that had been 
proposed by the previous administration were rescinded, and the ban on immigration by people living with HIV/AIDS was repealed (Henry, 2005).

\section{The 1990s}

It was not until 1991 that AIDS prevention and control became a national main concern at the peak level under the new prime minister. He took several steps that since have been credited with helping to slow the epidemic.

First, the AIDS control program was transferred from the Ministry of Public Health to the Office of the Prime Minister, growing its political influence, and the budget was raised almost 20-fold to \$44 million in 1993.

Secondly, the substantial public information campaign on AIDS discussed earlier under the leadership of cabinet member Viravaidya was started, and every school was required to offer AIDS education classes. This media intensive and school education campaign launched a safe sex song which was converted from a Jingle Bells song so it could easily be sung and remembered (Garbo, 2000).

At first, the high-profile campaign was unpopular with the powerful tourism industry, which temporarily rejected it. However, once AIDS had a major place on the national agenda, opposition to the measures steadily faded and support increased (World Bank, 1997).

The “100 percent condom program” was launched. This program purposely intended to enforce consistent condom use in all commercial sex establishments. Free condoms were given out to massage parlors, brothels and prostitutes, and their clients were required to use them. Brothels that didn’t comply could be closed. Without this 
program, it is estimated that Thailand's national HIV prevalence would be ten times higher than it presently is.

A number of policies, such as mandatory reporting of the names and addresses of people living with HIV, who went to hospitals, were also canceled (World Bank, 2000). From 1992 to 1996, the National AIDS program received a dramatic increase in funding. The government offered it with more than $\$ 80$ million annually by 1996 , and:

(Morse, 2002) Every segment of Thai society played a role in AIDS prevention ... the government committed funds for research and backed private organizations that attempted to spread the word about how to stop AIDS. Even the powerful Thai military pitched in, running voluntary blood tests for soldiers.

According to a 1995 WHO report, over 3.5\% of military recruits aged 21 and over were reported to be HIV-infected in many parts of the country following a 1992 round of surveys, with a prevalence rate of 20 percent in Chiang Mai, northern Thailand.

The second plan, called "National Plan for Prevention and Alleviation of the AIDS Problem,” lasted from 1997 to 2001 and maintained the earlier effective programs, while approving a more holistic approach, which included mobilizing the efforts of communities and people living with HIV/AIDS (World Bank, 2000). During 1996 and 1997, a randomized controlled trial was carried out to study the condition of short-course AZT (zidovudine) to avoid mother-to-child transmission of HIV in Bangkok. This study confirmed that AZT reduced transmission of HIV from mother to child by 50 percent (Shaffer et al., 1999).

Following this, a number of pilot programs were initiated in Thailand. The successful results of the pilot studies led doctors in most provinces to demand 
government support for short-course AZT to prevent mother-to-child transmission of HIV. By 1999, AZT was being used in most hospitals in Thailand (Kanshana, \& Simonds, 2002).

In the late 1990s, the Asian Financial Crisis resulted in a major reduction and reorientation in the 1998 funds for AIDS prevention and control. Funding for medical interventions (including antiretroviral drugs and treatment of opportunistic infections) was scaled back extensively. Also, support for condom distribution was decreased (Pothisiri et al., 1998). By 2000, national funding for HIV and AIDS prevention was approximately one quarter less than it had been in 1997 (UNDP, 2004).

\section{0 onward}

In 2000, HAART ${ }^{4}$, an effective HIV treatment that involves the combination of three or more $\mathrm{ARVs}^{5}$, was brought into Thailand. In the following years, the number of people accessing this treatment grew dramatically, importantly reducing the number of people dying from AIDS.

In 2003, the government made an official commitment to ensuring adequate treatment for all people living with HIV, and set targets to improve access. As these plans have been carried out, the third "National Plan for the Prevention and Alleviation of HIV/AIDS in Thailand" (which runs between 2002 and the end of 2006), has worked towards the target of reducing HIV prevalence to less than one percent and providing access to care and support for at least 80 percent of the people living with HIV and other

\footnotetext{
${ }^{4}$ HAART : Highly Active Antiretroviral Therapy

${ }^{5}$ ARV: Antiretroviral
} 
affected individuals. By the end of 2005, national HIV prevalence was 1.4 percent, down from 1.8 percent in 2003 and more than 2 percent a decade earlier. ${ }^{6}$

\section{The Need for HIV Prevention}

Thailand once led the way in world HIV prevention ... that helped to reduce the national HIV prevalence. However, past successes seem to have lulled the government into complacency. Prevention programs received just 8 percent of the national HIV/AIDS budget in 2000, and by 2001 the level of domestic funding for HIV prevention was half of what it had been in 1997. (UNDP, 2004)

In 2006, UNAIDS reported that Thailand's government had reduced its HIV prevention budget by two-thirds in recent years. This decreased concentration on prevention is concerning, and is setting the public at risk. There are signs that the epidemic could develop in coming years, reports recommend that the rate of Sexually Transmitted Infection transmission has risen, condom use has reduced and risky sexual behavior is on the rise (The Nation, 2006).

Lacking new prevention campaigns, safe sex messages will be forgotten and a new generation will grow up unaware of the risks they face.

\section{Young people}

UNAIDS Country Coordinator for Thailand Patrick Brenny stated that:

"Public information, which was once ubiquitous, has dropped off the radar screen ... Thailand must revive its flagging HIV/AIDS awareness programs to reach out to a new generation of young people, who currently see the virus as a problem largely affecting their elders. They are clearly vulnerable to infection with HIV” (IRINnews, 2006).

\footnotetext{
${ }^{6}$ UNAIDS, 2006 Report on the Global AIDS Epidemic
} 
There have not been any mass public prevention campaigns accomplished in Thailand for more than a decade. This has led to a turn down awareness and an increase in risky sexual behavior, particularly among young people do not remember campaigns that were carried out during the 1990s. It is considered that around $85 \%$ of young Thais do not see HIV as something that they should be cared about, even though 70\% of all STI cases in Thailand occur amongst this group (IRINnews, 2006). Premarital sex has turned out to be more widespread among young Thais, but only $20-30 \%$ of sexually active young people are constantly using condoms (UNAIDS, 2006).

\section{Injecting drug users}

Thailand has not had a great deal of achievement in decreasing HIV among injecting drug users. Infection rates among injecting drug users have stayed extremely high, at 35-50\%, and are still increasing in some areas (UNDP, 2004). HIV does not spread only among drug users but to their partners and their children, and left unchecked the high infection rate among injecting drug users will maintain a reservoir for HIV transmission to the rest of the population.

HIV prevention for injecting drug users has not been a main concern in Thailand even though this way of transmission plays an important role in the spread of HIV (UNDP, 2004). In 2004, Prime Minister Thaksin addressed an international AIDS conference that the government saw the need to treat drug users as patients, not criminals, and planned to decrease transmission among drug users. Nonetheless, the plans that he outlined, which included free needle allocation and methadone treatments, have yet to come out. Since a heavy-handed government function to crackdown on drug trafficking 
in 2003, drug use has been driven secretively, making it harder for prevention campaigns to target this group (Human Rights Watch, 2004).

\section{Men who have sex with men (MSM)}

At this time, MSM are a major risk group in Thailand, accounting for about onefifth of all HIV infections. In Bangkok (Capital of Thailand), HIV prevalence among MSM grew from 17 percent to 28 percent between 2003 and 2005. HIV prevalence among MSM younger than 21 years of age tripled in the same period (Human Rights Watch, 2004).

It was not until February 2006 that Thailand's first campaign to prevent HIV among MSM was initiated. The seven-month campaign ... 'Sex Alert' is jointly run by non-governmental organization (NGO) Family Health Planning, the Ministry of Health and local NGOs. It intends to provide MSM with information on safer sex through magazine and radio adverts, text messages, posters and the Internet. Flyers, condoms and lubricant will also be distributed. (The Nation, 2006)

Before Sex Alert, MSM had commonly been disregarded by prevention campaigns and had not been featured in national AIDS plans. Sex Alert marks a welcome change, but it is necessary that more prevention campaigns target this group to stem increasing infection rates.

\section{Migrant workers}

There are approximately around 2 million migrant workers living in Thailand, however only around 700,000 are registered with labor authorities (The Nation, 2006). A lot of these labors travel from bordering countries for example Cambodia and 
Myanmar. They figure a main part of Thailand's workforce, but the complexities that they usually encounter such as language difficulties or afraid of arrest and deportation can prevent them from accessing information about HIV/AIDS, as well as healthcare and other social services. In general, awareness about HIV/AIDS among this group is really poor. Their unstable way of life can put them into contact with a higher amount of sexual networks than other people, increasing both the risk that they will become infected and that they will increase infection to other areas of the country (UNDP, 2004).

It is not easy to track the correct level of HIV infection among migrant workers, and rates different between areas. Studies have recommended that HIV prevalence among pregnant migrant workers is more than twice as high as the prevalence among pregnant Thai women. Woman migrants, particularly those drawn into commercial sex work, are mainly affected by the epidemic (UNDP, 2004).

\section{Sex workers}

The " $100 \%$ condom" program, which enforced obligatory condom use in brothels, played an important role in decreasing Thailand's HIV prevalence in the 1990s. Campaigns that decreased the demand for sex work also contributed to this decline.

The $100 \%$ condom program is still legitimately in place, although it does not seem to be followed as thoroughly as it once was. Sex work has turned out to be gradually more common, with a 50\% increase in the total amount of establishments proposing sex services recorded between 1998 and 2003. The majority of these establishments is not brothels, and is not reached by the $100 \%$ condom program. Women who solicit sex in illegal venues, for example bars and restaurants, are not thought to use 
condoms frequently, and it is hard for authorities to monitor how they are being affected by the epidemic due to the unknown nature of their work (UNDP, 2004).

A greater concentrate on outreach work, where HIV prevention messages are put into effect through programs that gain access to networks of sex workers and promote peer-education, would be one way to guarantee that infection rates do not increase among sex workers that work outside brothels.

\section{Treatment for people living with HIV}

Since 2000, the government has given HAART to people living with HIV through over 914 public hospitals (Ford, 2004). Originally, branded drugs were mostly used, but a growth in the production of cheap generic drugs in Thailand has allowed the government to gain the medicines at much lower costs. The use of generic drugs led to over an eightfold increase in treatment provision between 2001 and 2003, with only a 40\% raise in budget (Ford, 2004). The national treatment campaign was enhanced by a US\$209 million grant from the Global Fund to Fight AIDS, TB and Malaria, most of which is being used to support the condition of ARVs. By the end of 2005, 60\% of those requiring ARVs were accepting them (UNAIDS/WHO, 2006).

Recently, though, Thailand's treatment agenda in specific the use of generic drugs has come under threat from international difficulties. The US has supported Thailand to sign a bilateral trade agreement, which would decrease its ability to create generic versions of patented drugs. This agreement, the US claims, would give drug corporations more inducement to develop new, better drugs, and to sell them to Thailand.

Nevertheless, many people are worried that the higher price of branded ARVs will lead to a situation where far fewer people will have access to treatment. 
"We fear that if the Thai government accepts the US proposal, doctors in Thailand will face substantial obstacles in providing treatment to their patients living with HIV/AIDS, especially for those that require newer antiretroviral (ARV) medicines to survive.” Paul Cawthorne, Medecins Sans Frontiers, Head of Mission in Thailand (Medicins Sans Frontiers, 2006).

The US government has been successful in establishing similar agreements with other developing countries. In taking this approach, it seems to be putting the rights of patent-holders prior to public health concerns. They argue that, by depending on generic drugs, developing countries decrease companies’ drive to develop new treatment. Others claim that this argument is defected, because companies that develop new drugs will still make enormous profits in developing countries where patent laws are much stricter (Oxfam briefing paper, 2006).

\section{The future}

"There are some very clear warning signals that the epidemic is on the move... you now have a recipe for a resurgence of HIV," said Hakan Bjorkman of UNAIDS (International Herald Tribune, 2005).

The government of Thailand needs to raise prevention efforts, especially among high-risk groups for example injecting drug users and men who have sex with men. With Prime Minister Thaksin lately overthrown by a non-violent military coup, Thailand’s political regulation is changing. It is likely that the new government will bring revolutions to HIV prevention, but whether the situation will develop or refuse is yet to be seen. If fast, successful action is taken, thousands of deaths could be avoided; otherwise, Thailand's past accomplishments will soon be forgotten: 
"There is still an opportunity to prevent resurgence, to nip it in the bud, but to do that the government has to focus on prevention, and that isn't happening” Swarup Sarkar, UNAIDS (International Herald Tribune, 2005).

\section{Media and AIDS}

\section{The Media and People Living with HIV \& AIDS Global Survey}

The findings below were conducted by INTERNEWS Network’s local Voices Program and the Global Network of People Living with HIV (PLHIV) and the media, which was completed by 130 PLHIVS from 44 different countries.

\section{Media are a vital source of information on HIV/AIDS}

The most important media sources of information are considered to be the Internet (72\%), followed by TV (65\%), newspapers and magazines (64\%), and radio (51\%).

\section{Local media are viewed as weak in HIV/AIDS coverage of PLHIV portrayal}

$>$ The quality of HIV/AIDS media coverage by local news media is judged to be either "poor” or "average," with very few (less than 10\%) judging coverage to be "very good."

$70 \%$ of respondents consider local media to provide the poorest coverage of PLHIV, 50\% of respondents consider national media to provide poor quality; International media were judged to be adequate to excellent by $66 \%$ of respondents.

$>$ The majority of respondents considered local/national TV to portray PLHIV in the poorest manner (71\%), followed by radio (64\%) and then newspaper (60\%). 
The main factors influencing media portrayal of PLHIV are judged to be “ignorance” (70\%), closely followed by “stigma” (73\%), “judgment” (72\%), "lack of research” on the part of journalists (66\%), and a tendency towards sensationalism (60\%).

\section{Improving Local News and HIV/AIDS}

Local news media coverage of HIV/AIDS is improving across all mediums - radio, TV and print media - according to respondents. $71 \%$ consider local radio to have improved or somewhat improved, $70 \%$ for TV, 70\% for newspapers, and 63\% for magazines.

Areas of strong improvement are "more voices of people with HIV/AIDS" (36\%), and "less focus on infection” (33\%), and areas of some improvement are "more focus on living positively” (38\%), “more focus lessening stigma” (40\%), “less inaccuracies” (41\%), “less judgmental tone” (45\%), “less sensationalism” (39\%). “Respect for confidentiality” is said not to have improved, however (33\%).

\section{PLHIV experience with local media has been mixed}

The majority of respondents say that local news media coverage of themselves has caused then “embarrassment” (59\%), “stigma from neighbors and community" (53\%), and to have their "jobs endangered” (50\%). However, 59\% also said that their portrayal in the local news media has caused them or other local PLHIV to be more "understood in our community" (59\%), to be more "respected" (49\%) and to feel more “encouraged” (50\%). 
Respondents have experienced both a high degree of disrespect and stereotyping by local news media, but also nearly half have also had the experience of respectful and non-stereotyping portrayal by local news media. Most respondents say that they have been quoted accurately in the local media (53\%); however, a large minority has been misquoted on occasion (41\%).

Most respondents have experienced some media engagement, and their relationship with local media is largely proactive; $74 \%$ have been interviewed by a journalist, 59\% have been photographed, just over half of respondents have participated in local radio or TV programming or have actively contacted newspapers.

\section{PLHIV desires for local media}

The most important topic that respondents want covered more fully in local news media is "stigma and discriminations of people with HIV/AIDS” (96\%), followed by “funding for HIV prevention, care and treatment” (87\%), and “youth and HIV” (84\%).

The more effective formats are judged to be ones that include local PLHIV voices - these include "human interest stories” (45\%), "talk shows with experts and/or a panel” (41\%), “drama” (39\%) and "news and current affairs" (38\%). The more traditional media formats are viewed as less effective: "newspaper ads" (48\%), "letters to the Editor” (44\%) and “public service announcements” (36\%). 


\section{Improvements through greater engagement}

Respondents believe the way to assist local news media is to improving its coverage of HIV/AIDS and its portrayal of PLHIV is to work together more closely and to engage more fully. 99\% agree that "more outreach to media by PLHIV networks" is necessary, and 97\% agree that "more interaction between PLHIV and the media” (97\%), and "better media strategies and advocacy by PLHIV to the media” (97\%) are key.

Respondents would like to see media being more proactive in encouraging PLHIV to be part of the media itself; with $87 \%$ wanting “more PLHIV in newsrooms.” Respondents strongly endorse “a code of conduct for media about HIV/AIDS” (87\%).

Training for both parties to understand each other more fully and work together more effectively was also strongly endorsed; “more training of PLHIV organizations on media engagement” (93\%), and “more training for media on HIV and AIDS” (96\%). 
The statistics below are from a 2006 UNAIDS report on the global AIDS epidemic:

\section{Table 1: The Current Situation}

\begin{tabular}{|l|l|}
\hline Estimated total population, July 2005 & $64,233,000$ \\
\hline Estimated number of people living with & 580,000 \\
\hline HIV, end 2005 & 560,000 \\
\hline Wdults (15+) & 220,000 \\
\hline Children (0-15) & 16,000 \\
\hline Estimated adult HIV prevalence $(15+)$ & $1.4 \%$ \\
\hline Estimated number of AIDS deaths in 2005 & 21,000 \\
\hline
\end{tabular}

$>$ The majority of Thailand's HIV infections (about 80 percent) occur through heterosexual sex.

HIV affects more men than women in Thailand; the male-female ratio is nearly 3:1.

HIV prevalence among pregnant women, which reached a peak of 2.35 percent in 1995, had fallen to $1.18 \%$ by 2003 . 
The distribution of antiretroviral drugs has coincided with a dramatic drop in the number of officially reported AIDS-deaths - from 5,020 in 2004 to 1,640 in 2005. The AIDSCAP report espoused that national political and economic interests can have the most influence to a country's response to the HIV/AIDS epidemic. Had Thailand's press been controlled solely by the government or at least heavily funded by the government, it is unclear how the media would have reacted to the initial leak of the HIV/AIDS epidemic. Thailand's extensive free and sentinel surveillance system enabled a handful of concerned people to detect the emergence of a widespread epidemic, and the findings helped to force the government into action. Publication of sentinel survey results by the mass media was one of the most important catalysts for HIV/AIDS policy development in Thailand, and the AIDSCAP report emphasizes the importance of an independent media (Henry, 2005).

A representative of an international HIV prevention agency in Bangkok said, "An open and unrestricted commercial mass media gives credibility to government information about the epidemic," It provides the only forum for the national policy dialogue necessary to reform societal norms to combat HIV (Henry, 2005, p. 5). This is where the main point of possible contention will happen. It is universally accepted that a free media needs to exist. And it is also universally accepted that to have a free media, the government should avoid any involvement with the operations of the media. In a democratic society, such as the one Thailand claims it is striving to become, media rights and freedom are guaranteed by the Universal Declaration of Human Rights, Article 19 (adopted and proclaimed by General Assembly resolution 217 A (III) of 10 December 1948), which states, "Everyone has the right to freedom of opinion and 
expression; this right includes freedom to hold opinions without interference and to seek, receive and impart information and ideas through any media and regardless of frontiers.”

The Thai media are also protected by provisions in the Thai Constitution of 1997. In this Constitution, Article 37 guarantee an individual's "right to lawful communications" while Articles 39 and 41 guarantee the right of public members and the media to report news and express views that are not against the professional code of ethics. In addition, Article 40 of the Constitution regards communication and broadcast frequencies as "national resources that should be used for the benefit of the public." However, in practice, in Thai history, these principles have been largely ignored, giving rise to continued violations and threats against media freedom by their own government.

With Thailand's past history of government intervention and abuse of the media, one can only wonder at the possible outcomes of a funding partnership between the Thai media outlets and their national government.

Therefore, the basis for this exploratory research project is as follows:

The basic need for cooperation between the Thai media and the government for the reporting of HIV/AIDS related news is apparent; but it is the slippery slope which can, and probably will, cause problems down the road. If the current press of Thailand accepts government funding and participates in a nationalized, government led program for HIV/AIDS awareness, the press has, in effect, relinquished its ability to be impartial and is now under the control of the government. The research questions listed helped address that very point.

AIDS coverage in Asian countries has been infused with the themes of denial, blame attribution, and agreement (Bardhan, 2001). Coverage has been inadequate 
because government control is very powerful in press systems in this area. Lim (1995)

found that the coverage of the pandemic in Malay language and English language

newspapers in Malaysia was not enough, prejudiced, used frequently government sources, labeled AIDS as the infection of uncharacteristic people, and held homosexual populations, injecting drug users, and sex workers responsible for the increase of the virus. Thailand has two systems of the press: State controlled media outlets and Independent media outlets. Given the fact that Thailand's government press is under tight government control, the government influences on mass media are dominant in manipulating news sources and shaping the news content.

\section{Sources as a force on media content}

Sources have an effect on mass media content “because journalists can’t include in their news reports what they don't know” (Shoemaker and Reese, 1996, p. 178). Gans (1979, p. 80) described sources as the "actor whom journalists observe or interview, including interviewees who appear on the air or who are quoted in ... articles, and those who only supply background information or story suggestion.” The sources of reporting are important to study because they conclude not only what information is distributed to the public, but what image of society is portrayed (Soloski, 1989).

Sigal (1973) described routine channels of news sources as formal proceedings, press conferences, and press releases as well as non-spontaneous events, for example functions and speeches. There are numerous sources vacant in each news event that reporters may attain; nonetheless, not all sources are likely to be used by journalists.

Sigal (1973) discovered that $81.3 \%$ of the sources were government officials in the front page stories in the New York Times and the Washington Post. In a similar study, 
Brown, Bybee, Wearden and Staughan (1987) found that 55.4\% of sources were associated with government branches.

Shoemaker and Reese (1996, p. 181) advised that "official sources are favored by journalists not only because they are more easily available for an interview but also because journalists and their editors believe that official sources have important things to say and tend to accept the things official sources say as being factual.”

The specialist is another essential source contributor to reporters. Reporters greatly rely on specialists to explain their meaning and put events into context (Shoemaker and Reese, 1996). Journalists become specialists for more truthful analysis of the meaning of news events, in order not to obviously state their own opinions in the stories.

Shoemaker and Reese (1996) note that each source supplies reporters with different messages and perceptions. Journalists can shift, discard, and choose through the information they are offered or cover and come up with news stories. As advised by Shoemaker and Reese (1996) noted, they mostly pressure the media content in more subtle ways, such as giving the context within which all other information is valued, or taking over reporters' time so that they do not have an occasion to use sources with different views.

Stempel and Culbertson (1984) discovered that physicians were the most common sources of health care news. Cassidy (2000) realizes that government, scientific, and medical sources were the most important sources developed in stories by investigating eight well-known newspapers in the U.S. In a study of AIDS coverage by The Washington post, The New York Times, The Los Angeles Times, and The Chicago 
Tribune for the period 1983 to 1989, 90\% of the stories were found to have initiated from official medical journals and conferences (Walters \& Walters, 1996). Brodie et al. (2004) ultimately found that worldwide AIDS conferences have more and more become key news-generating events.

Another phase of source selective involves journalistic routines, news sources, or the metaphorical perception of news stories (McCombs, 1992).

This includes agenda setting and building, a perception used in political science studies and employed by Lang and Lang (1983) to look at the affiliation between the press and public opinion during the Watergate crisis. Agenda building encompasses numerous steps (Walters, Walters and Roger, 1996), the ones most appropriate to this research are as follows:

D The press emphasizes certain issues, leading those issues to be noticeable.

$>$ Issues must be framed for audiences; that is, media must afford audience members with a common sense of an issue and its meanings.

Agenda building picks up speed when well-known individuals turn out to be involved.

Gilburg, Eval, McCombs and Nichols (1980) noticed that President Carter had little influence in media stories in the period following his 1978 address and inferred that the media set the president’s agenda more willingly than vice versa. 


\section{RESEARCH QUESTIONS}

This research project will answer the following questions to help gain a broader perspective on this issue of media coverage of AIDS in Thailand:

RQ1: Do Thai journalists believe that accepting money from the Thai government for a nationalized campaign on HIV/AIDS would have a positive or negative impact on the future of a Thai press and the prevalence of AIDS?

RQ2: Which of the four theories of the press - authoritarian, libertarian, social responsibility, or communist concepts - do Thai journalists seem to most embrace today? RQ3: Do members of Ministry of Public Health believe that giving money to the Thai press will help quell the spread of AIDS faster than allowing voluntary reporting of the disease? 


\section{CHAPTER 3}

\section{METHOD}

The primary method of the research questions which I chose to use was the indepth interview method. Interviewing was conducted on December 18, 2006- February 16, 2007.

The in-depth interview method was well suited to answer the research questions. An in-depth interview guide (see Appendix A for a list of questions) was prepared to lead discussions with the government media journalists, private media journalists, and Ministry of Public Health of Thailand officials. I used the method of snowball sampling by selecting a small group of Thai journalists $(\mathrm{N}=12)$. The initial journalists selected were my acquaintances and all subsequent selections were based on the knowledge or acquaintanceship or colleagues of the primary group. These journalists were both from State controlled media outlets $(\mathrm{N}=6)$ and from private/independent media outlets $(\mathrm{N}=6)$. There were six television journalists, four newspapers journalists, and two radio journalists from three television stations, four newspaper companies, and one radio station.

This was necessary because there were two distinct journalist mindsets of the proper way for reporting on HIV/AIDS. Also, I interviewed six Ministry of Public Health officials by using the same type of snowball sample. I recorded titles and publications in the thesis to share with my committee. I received honest responses and would only publish identifying information of interviewees who allowed me to put their information in this thesis. I called, emailed, and interviewed them in person while I was in Thailand. I 
took notes and taped record my conversations, when respondents agreed, and transcribe them.

However, some respondents were not be comfortable with a recording, so I took notes and asked questions to clarify their statements when in doubt.

In all eighteen people were interviewed to help me explore answers to my research questions, and answer in discussion section.

Analysis of the qualitative data collected through in-depth interviews was completed immediately after each interview. A verbatim record of individual in-depth interviews was typed immediately to ensure entirety, constancy and accuracy. These records were analyzed and summarized and any common themes, ideas, and responses were noted. 


\section{CHAPTER 4}

\section{RESULTS}

The results from the in-depth interviews follow:

$>$ Six government controlled journalists

Six independent media journalists

Six Ministry of Public Health of Thailand's officials

RQ1: Do Thai journalists believe that accepting money from the Thai

government to reporting on HIV/AIDS would have a positive or negative impact on

the future of Thai press and the prevalence of HIV?

Government controlled journalists:

\section{Journalist \#1}

Sarawut Putthakun, a reporter from the Royal Thai Army Radio and Television Channel 5 said that granting money directly from the Thai government, especially on AIDS coverage, is not an appropriate thing for the government to do, even though it can support and subsidize journalists. It would look like under table money or bribery. Journalists would not be comfortable reporting news and feel insecure because they would be catering more to what the government wants journalists to report. "I think that the distribution of money for journalists could be risky and could be a bribe to media's coverage of news reporting,” Sarawut said.

Moreover, Sarawut suggested that if the government really wants to support journalists, the government should set up a media fund organization and journalists could accept funds through this organization. It would be more appropriate and better than 
accepting government money. This way the allocation can reach reporters, but not have power over journalists.

He affirmed that the AIDS story is still a big issue in Thailand's society. To provide AIDS information is really necessary for the public, so people can clearly understand this epidemic. Journalists should be working for their own press company and writing for the people, not for someone that gives money to write the news for them. This kind of thing can have a negative impact on the future of the Thai press.

\section{Journalist \#2}

Chonratsamee Nga-Taweesuk from the Royal Thai Army Radio and Television Channel 5 said “I don’t agree to accepting federal money because media will not be able to work independently if we obtain money from the government. One of the principles of our career that we embrace is to work autonomously along with a code of conduct without anyone controlling us.”

She also said that journalists will lose their freedom to report on AIDS/HIV. For example, the government might cover up a fact about the number of people living with AIDS in some areas in Thailand because the government doesn't want it to have a negative effect on the country’s tourism. Therefore, the money might help conceal the truth in this situation.

\section{Journalist \#3}

Tapin Kraiwanich, a journalist from Television Channel 11 (controlled by the Government Public Relations Department), said “I don’t think that there’s anything that can hurt the future of Thai press if journalists accept federal money; it would even have more of a positive impact for us.” 
She stated that nowadays the Thai government has a budget for media to cover the AIDS story, both domestically and internationally, so the media would not have any disadvantages to take federal money.

\section{Journalist \#4}

Chuchat Tedseedang, a journalist from Television Channel 11 (controlled by the Government Public Relations Department) said, “It is absolutely a positive impact on the future of Thai press if we receive money from the government. I don't see any problems with it.”

Three years ago, the Thai Press Association had funds from foreign countries to do AIDS coverage by selecting journalists from all over Thailand to attend a media training program to learn more about reporting on AIDS in a proper way by foreign speakers who had experiences in this field,” Chuchat said.

\section{Journalist \#5}

Lieutenant-senior R.N. Likid Youngyuen, an assistant director of Voice of the Royal Thai Navy Radio 5 Pattaya said that accepting money from the government would definitely have a negative impact on the future of the Thai press in the long term because

journalists will make money from the government. Depending on that money would have an effect on the news or AIDS story. Journalists will perform an injustice and launch too much unnecessary news or AIDS stories. “I’m afraid that in a long run, the government might use the money in the wrong way, for example, buy journalists, buy news, and end up buying a media organization,” Youngyuen said.

Youngyuen suggested that instead of the government giving money to the Thai press, the government should promote an AIDS awareness campaign and give the money 
directly to the Ministry of Public Health. It is the Ministry’s responsibility to promote AIDS awareness; they have extensive information about AIDS. The Ministry of Public Health then might contact the press for a story or the press should contact the ministry; this way would be the fairest way and money would not me an issue of concern.

\section{Journalist \#6}

Mr. Suppachai, a reporter from Voice of the Royal Thai Navy Radio 5 Pattaya said, "It's not a good idea to accept money from the government to report on AIDS; it would be definitely a harmful influence on the Thai media as a whole.”

Journalists consider remuneration as an illegal thing to do. "We have our own judgment to report on AIDS, what should and should not be broadcasted without anyone telling us what to do,” said Suppachai.

\section{Independent media}

\section{Journalist \#1}

Wisut Mungmee, a TV program editor from Thai Independent Television (iTV) said, "I really concur with accepting federal money to report on the AIDS story because journalists will have enough money and it would encourage them to work on AIDS coverage, and therefore disseminating AIDS awareness, which is very important to Thai people.”

Wisut recommended that the government should act professionally and be honest; do not try to use that money in an illegal way. The government should clearly set a goal for AIDS awareness, rather than just giving money to journalists. An example would be, how many times the audience should see the AIDS story, controlling the AIDS content in 
order to reach the goal, expanding an AIDS campaign to promote a good image for Thailand and the Thai press.

\section{Journalist \#2}

Suppachok Opasakhun, a reporter from Thai Independent Television (iTV), stated that because of the nature of the audiences, no one sticks with the same news or same stories all the time. They will always change their interests depending on what story is popular in that time. If the government really wants to support the Thai press, it would be better if the government generates a short time program or an AIDS documentary on television. For example, five minute AIDS programs shown at an appropriate time. Once again, as a journalist, Suppachok believes that the media can not televise too much on the AIDS story because there's other news that is also important and is considered as newsworthy. Too much of the same news makes audiences bored.

\section{Journalist \#3}

Jitwadee Pengmak, a journalist from Dailynews Newspaper, said that if journalists accept money from the government, it would go extremely against the ethics of journalists. Journalists work directly for their own company or publishing house, journalists will not accept anyone’s money except our own salary. Journalists are assigned tasks by our boss or company, not by the government, she said.

“If journalists get money from the government, which means we work for others not for our own boss, the report will automatically promote the government,” Pengmak said. 


\section{Journalist \#4}

Rattapon Kumhom, a journalist from Post Today Newspaper said, “I don’t see any drawbacks if journalists accept federal money to report on AIDS, it wouldn't be different or affect the country because AIDS awareness is a good story that people should be aware of anyway.”

"It would be a positive impact on a Thai press, therefore paying for media coverage could be common among Thai journalists”, Kumhom said.

\section{Journalist \#5}

Sirichai Watchareenun, a director of Kao-Na Local Newspaper, Chachoengsao province said, "I strongly believe that federal money will help a Thai press on AIDS issue a lot. It would also be a benefit to audiences to get precise information on the AIDS since journalists have enough money to rely on”

“Journalists might not be able to go to every place that is considered an informed place due to insufficient funds. This also includes other issues, such as drugs, illegal gambling houses, not only AIDS related ones,” Sirichai said.

\section{Journalist \#6}

Boonlert Buddhachareon, a journalist from Prachathai Local Newspaper, Petchaboon province said that it's an extremely good impact on a Thai press because journalists will not have any pressure from other organizations. If there are any problems or concerns, people can directly blame the government, not journalists, because the money is from the government. Journalists can only do what they can by serving the government. 
RQ2: Which of the four theories of the press - authoritarian, libertarian, social responsibility, or communist concepts - do Thai journalists seem to most embrace today?

\section{Government controlled journalists:}

\section{Journalist \#1}

Sarawut Putthakun, a reporter from the Royal Thai Army Radio and Television Channel 5, said that after September 19, 2006, where a military junta overthrew Thaksin Shinawatra, a previous Prime Minister, the way of Thai press seems to have more independence of expression according to the Constitution of Thailand, 1997 in Article 39 states, “A person shall enjoy the liberty to express his or her opinion, make speeches, write, print, publicize, and make expression by other means.” This shows that Thai journalists mostly embrace the libertarian concept. On the other hand, as we were under

Prime Minister Thaksin, we were interfered with the government. For example, they shut down a print house if a press reported something against his political party or revealed suspicious corruption.

“As you can see from CNN, an interview of Prime Minister Thaksin in Thailand, this should prove Thai press has no limit in presenting news even from a foreign medium," Sarawut said.

Moreover, Sarawut stated that journalists are normally able to criticize a government in both good ways and bad ways without media interferences.

\section{Journalist \#2}

Chonratsamee Nga-Taweesuk from the Royal Thai Army Radio and Television Channel 5 said that Thai press is a quite libertarian concept, which means Thai press is 
not totally controlled by a government; Thai press has the right to show their opinions, but still not fully to be free from capitalism. Thai press still depends on the "Ownership” or "Proprietor" for whom they work. For example, if a journalist works for a military media outlet, he can not report a negative image of the military.

\section{Journalist \#3}

Tapin Kraiwanich, a journalist from Television Channel 11 (controlled by the Government Public Relations Department) said that Thai press most embrace libertarian concept when journalists have to express their views and expose news to audiences and in the terms of government's image, but a social responsibility concept seems to fit in the most today for example, a government launches a special AIDS event.

\section{Journalist \#4}

Chuchat Tedseedang, a journalist from Television Channel 11 (controlled by the Government Public Relations Department), “It depends on who is a prime minister and what is a government policy at that time,” Chuchat said.

In the case of the former Prime Minister, Thai press was authoritarian. For example, if a paper printed something that was not good about him, then he and all of the cabinet of the government would withdraw all of their advertising business. "Everybody has to serve someone in other word is everybody has to flatter their bosses," Chuchat said.

Chuchat also said the concept that Thai press most embrace today is still the authoritarian concept, even though the government has changed. However, most of the reporters are the same, same business media, same country, therefore Thai press still adhere to the same principle. 


\section{Journalist \#5}

Mr. Suppachai, a reporter from Voice of the Royal Thai Navy Radio 5 Pattaya, said that Thai journalists most embrace is a combination of libertarian and social responsibility. He suggested that Thai journalists should not only portray their point of views, but also need to be responsible to government policy as well as media recipients.

\section{Journalist \#6}

Lieutenant-senior R.N. Likid Youngyuen, an assistant director of Voice of the Royal Thai Navy Radio 5 Pattaya, stated that libertarian and authoritarian are most embraced today. In the case of libertarian, journalists report too much news that should not be reported just because they want to obtain high ratings, which means they will get a lot of money from their sponsors. If that news is a hot issue in that time, they will keep publicizing without concern about ethnic or people who are under age, who should not receive such information.

However, Thai press also works for their employers; they must not reveal a bad side of their company, which they work for, Likit said.

\section{Independent journalists:}

\section{Journalist \#1}

Wisut Mungmee, a TV program editor from Thai Independent Television (iTV), said that according to the Thai constitution of 1997, Thai correspondents have thoroughly the freedom to say, write, show their viewpoints. On the other hand, Thai correspondents are under government power, especially if a current government is a military. Thai press still has media interventions by government. Therefore, Thai press embraces both libertarian and authoritarian. 


\section{Journalist \#2}

Suppachok Opasakhun, a reporter from Thai Independent Television (iTV), addresses that authoritarian and libertarian ideas are currently embraced. Thai press has the liberty to showing their attitudes, but at the same time Thai journalists still are under control by their capitalists, bosses, and employers. For example, Channel 3 avoids condemning a businessman or capitalism because Channel 3 is run by a Maleenon family or entrepreneurship; Channel 5 stays away from criticizing the government and military because military is a board of directors; Channel 11 keeps away from reporting a bad side of government; it always provides a good image of government to viewers for the reason that Channel 11 belongs to a Thai government.

\section{Journalist \#3}

Jitwadee Pengmak, a reporter from Dailynews Newspaper said that Thai press today seems to be libertarian because the way journalists present the news is very free, which is different from the past. "The press in the past was more threatened by the government than today,” Pengmak said.

\section{Journalist \#4}

Rattapon Kumhom, a journalist from Post Today Newspaper, stated that Thai press right now is slightly overlapped between libertarian and authoritarian. Thailand is a democracy country which should be totally free in coverage of the news, but the government still has power to manage a press. For example, the current government does not want media to broadcast anything about a former prime minister, a government does not want people to misinterpret and have a conflict with a previous government, which is a different attitude from journalists. In journalists’ point of view, a government should 
not put pressure media. Thai press should be able to disclose the truth and information to public.

\section{Journalist \#5}

Sirichai Watchareenan, a journalist from Kao Na Local Newspaper, Chacheongsao province, believed that Thai journalists at present are libertarian and authoritarian. In terms of unanimity, journalists have complete self-determination to express their views as long as they do not go against anyone because government wants to increase unity with Thai people. However, a government will control the press if the news coverage stirs up disagreement among Thai people, government, groups, society.

\section{Journalist \#6}

Boonlert Buddhachareon, a journalist from Prachathai Local Newspaper, Petchaboon province, said that Thai press is now a combination of libertarian and authoritarian, which is caused by media having extreme influence on people. Media can expose information to people at the same time, media can shut down their points of view and news coverage because a government does not want or need people to know.

"Media can give people the right information as well as mislead people with mistaken information,” Boonlert said.

RQ3: Do members of Ministry of Public Health believe that giving money to the Thai press will help quell the spread of AIDS faster than allowing voluntary reporting of the disease?

\section{Government official \#1}

Dr. Surat Lek-Uthai said that money is not a major factor to change people’s attitude about AIDS or other pandemics. Although, it depends on news consumers and 
journalists' activities such as how well people understand the news content, how often they receive the news, how they react to the news, and journalists should be skillfully trained. I think those factors are more likely useful and can change the spread of AIDS than accepting money from Ministry of Public Health. Media also have a big influence on Thai society, so whatever the media portray, people will receive and analyze from it. Media have responsibility to provide useful, accurate and up to date news as well as a professional performance.

\section{Government official \#2}

Pattaneeya Pojanavetin, a technician officer of Ministry of Public Health, said, "I don't believe that giving money to journalists will stop the spread of AIDS/HIV quicker than letting voluntary reporting of the disease, since an AIDS matter should be something that everyone has to be responsible for and be aware.”

"I truly admit the fact that money can encourage journalists, but if considering an ethic of press, journalists shouldn’t be motivated by money,” said Pattaneeya.

Pattaneeya stated, “It’s everybody’s duty.” Media have such a large impact on the AIDS epidemic, thus paying money to media should come from every government branch or non- profit organizations. Every institution and everybody in Thai society should be collaborating together and take serious this issue, so that will help quell spreading of AIDS, not only focus on Ministry of Public Health.

\section{Government official \#3}

Atchara Boonchum, a technician officer of Ministry of Public Health, said, "I believe that giving money to journalists can’t help reduce the disease of AIDS at all.” 
Atchara said that if Ministry of Public Health offers money, they might distort and twist the message, they might change words to make it sound soft and it is bad for people when people receive the news. They will not be afraid of AIDS, therefore giving money will not help stop the spread of AIDS faster than allowing unpaid reporting about the disease.

\section{Government official \#4}

Watcharin Teeratikasikorn, a Ministry of Public Health officer, said that she does not believe that providing funds will reduce the spread of AIDS. Everybody should be responsible for the AIDS issue, not only journalists or Ministry of Public Health. For example, if the ministry pays a billion dollars on AIDS coverage, but people still ignore this topic, a billion dollars are totally devastated, this shows that no matter how much money the ministry puts into, it can still not help stop the spread of AIDS. As long as people do not pay attention to this issue, the spread of AIDS will not be reduced.

About the media role, Watcharin suggested that journalists should be the voice of the society who can urge the government to change negative attitudes about concern and treatment of the AIDS disease.

\section{Government official \#5}

Dr. Usaha Prukjirawong, a Ministry of Public Health officer, stated that he believes that paying money to a press will definitely support journalists and motivate them to work hard, so that results in refraining of AIDS prevalence faster than letting voluntary reporting about the disease.

“The role of media is to gather and provide information to a public; journalists

have this principle in their mind, so if they are paid, I think they're more willing to work 
and put their effort into their job, which means the news coverage of the epidemic can go forward, more truthful, informative and authorizing reporting,” Usaha said.

\section{Government official \#6}

Kruetip Khunkrong, a Ministry of Public Health officer, said that the ministry does not give money directly to journalists, but only gives small amounts of money for accommodation, gas, food, traveling, when journalists have to go out of town or there's a press tour. The ministry will provide a press release for journalists. If the story turns out to be a hot issue in that time, then it will be broadcasted by a media company.

“I don’t believe that giving money to a press will stop AIDS. The AIDS issue should be something that everyone must become aware of, no matter how many times journalists launch an AIDS story,” Kruetip said. 
Table 2: Summarizing the journalists interviewed

\begin{tabular}{|c|c|c|}
\hline Status & Number & Percent (\%) \\
\hline \multicolumn{3}{|l|}{ 1. Gender } \\
\hline Male & 5 & 41.67 \\
\hline Female & 7 & 58.33 \\
\hline \multicolumn{3}{|l|}{ 2. Age } \\
\hline $20-35$ & 5 & 41.67 \\
\hline$-\quad 36-50$ & 4 & 33.33 \\
\hline$-\quad 51-65$ & 3 & 25.00 \\
\hline \multicolumn{3}{|l|}{ 3. Media } \\
\hline - Government & 6 & 50.00 \\
\hline Independent & 6 & 50.00 \\
\hline
\end{tabular}

Of the journalists interviewed, 58.33\% believe that accepting federal money to report on HIV would not have a positive impact on the future of the Thai press. $41.66 \%$ believe that accepting federal money to report on HIV would have a positive impact on the future of the Thai press.

In addition, 83.33\% believe that accepting federal money to report on HIV would have a positive impact on decreasing the prevalence of HIV; $16.66 \%$ believe that accepting federal money to report on HIV would not have a positive impact on decreasing the prevalence of HIV.

Of those interviewed, 58.33\% believe that a combination of libertarian and authoritarian concepts Thai press most embrace today; $25 \%$ of sample group believe that 
a libertarian concept is most embraced today; $8.33 \%$ believe that a social responsibility concept is most embraced today; $8.33 \%$ believe that an authoritarian concept is most embraced today. 


\section{CHAPTER 5}

\section{DISCUSSION, LIMITATIONS AND FUTURE STUDIES}

Two main research questions in this study are about the attitudes of a Thai press on what they think about accepting federal money to report on HIV. Another main research question is about the attitudes of the Ministry of Public Health of Thailand about giving money to journalists to report on the AIDS story.

From the results, I found that most of journalists' attitudes do not believe that accepting federal money to report on AIDS/HIV would have a positive impact on the future of Thai press because journalists have their own media owner to work for as well as their professional ethics of journalists, that means journalists can express their opinions as long as they practice under a standard of morality. Media professionals should know that freedom of expression must go along with human rights.

“The media responsibility is very imperative in building understanding of AIDS prevention and to promote technology for the development of AIDS treatments," said Tepin, Channel 11.

Journalists obtain salary from their employers and journalists can not report anything against their company's image, so journalists are responsible to report accurate, truthful and informative news without receiving money from the government. Another thing is that if they are paid by the government, journalists will lose their liberty to report, and all the news will depend on what the government wants it to be like, which means money can change the message by controlling the press, so the press will unwillingly deform the news. 
Instead of giving money to a Thai press to report on AIDS, government should work with the media by putting an effort into creating an AIDS campaign. "AIDS is not just a health problem, it's also a problem of economy, development and tourism of Thailand,” said Supachoke. "Journalists have a significant role to play in the HIV and AIDS epidemic, by informing the public and holding governments to account," said Christopher Warren, president of International Federation of Journalists.

The government should make more effort to make people aware the fact that HIV is still a serious hazard. People should not only count on the journalists in the fight against AIDS, but the government should play a more energetic role as well to publicize information that helps raise public awareness of AIDS risks.

Moreover, training journalists would develop better reporting on AIDS. Government should be concerned about training journalists to improve journalists’ role toward reporting on HIV and other news coverage.

On the other hand, some journalists believe that federal money would help reduce the prevalence of AIDS and make people better understand the treatment of AIDS because journalists can use that money to build up AIDS coverage, reach more audiences, and have more money to promote and distribute AIDS stories and campaigns. Journalists would have the funds to do in-depth research and interviews in some rural areas in Thailand because they would have money to travel to go to faraway places.

"AIDS awareness and treatment campaign needs to be financially supported by government,” said Suppachai, Voice of the Royal Thai Navy Radio 5 Pattaya.

From the results, most of journalists think that a combination of libertarian and authoritarian is the concept that Thai press most currently embrace. These two concepts 
of the press depend on who is a prime minister at that moment. "Thai press is like a tree that can change a color every season,” said Youngyuen, an assistant director of Voice of the Royal Thai Navy Radio 5 Pattaya. Younyuen gave an example that can help explain the Thai press situation: a talk show Muang Thai Rai Subda Channel 9 was banned by a former prime minister because a host was debunking corruption. Even though he had the freedom and right to disclose government activities, eventually this talk show was forbidden by the government.

In Thailand, this combination of authority and libertarian concepts results in selfcensorship. Some people in the U.S. fear media self-censorship of economic and corporate issues, owing to the consolidation of media outlets. However, political issues still are widely debated and lampooned in U.S. media. Future studies could look at the U.S. media in terms of Siebert's media theories and how journalists believe our system operates today.

According to a 2005 report about AIDS reporting and the media environment in Southern Africa, there area number of barriers to good reporting on the issue. These include the following:

Lack of access to accurate information about the epidemic.

$>$ Curbs on freedom of speech and oppressive government policies affecting access to information and freedom to scrutinize policies affecting HIV/AIDS. Limited personal understanding about issues, trends and changing dynamics in the epidemic due to lack of training. 
Lack of resources, including money, time and equipment, to travel and investigate HIV stories, leading to an over-emphasis on HIV in urban areas and neglect of rural populations.

$>$ Ethical dilemmas, such as the tension between the need to respect a person's confidentially and the need to provide a platform for the voices of people affected by HIV/AIDS.

Self- censorship, as a response to cultural taboos, such as open discussion of sexual behavior or analysis of gender roles.

$>$ Competing topics on the news agenda and perceived AIDS fatigue by editors, as well as audiences, resulting in a lack of editorial support.

$>$ The need for new, imaginative approaches to creating AIDS stories and programs appropriate to different media such as community radio.

In terms of moral responsibility when reporting on HIV, many of these points were confirmed by the Thai journalists who were interviewed. Journalists should make sure that the voices and images of AIDS victims are covered. Their faces should not be shown. “AIDS patients already live with downhearted situations; journalists should ensure that they will not do anything to make AIDS victims feel worse,” said Tepin, a reporter from Channel 11. Reporters should respect the rights of AIDS victims. They should not be intimidated. Journalists should receive permission before intruding on their privacy.

Although, this idea of paying journalists had been discussed by the Ministry of Public Health, this study found that Ministry of Public Health officials do not believe that paying for media coverage would help quell the spread of HIV and the prevalence of 
AIDS faster than allowing voluntary reporting on HIV because the AIDS issue does not belong to only Ministry of Public Health or journalists, but it is everyone’s.

“It’s everyone’s duty,” said Pattaneeya, a health technician officer.

Officials also echoed some of the same sentiments as journalist. For instance, some believed governments, media, people, relevant authorities and civil society groups should band together to be engaged in freedom of information and AIDS awareness. Everybody should be worried about AIDS; it can cause many problems to the country. Furthermore, standard and sustained training for editors and journalists on HIV reporting would be better than giving money to journalists, which would better help diminish the spread of AIDS. Allowing voluntary in reporting on HIV is the best thing that the ministry should do; the ministry just provides the useful information about the disease and is a consultant for journalists. People can receive honest and transparent information, and nobody tells journalists to write to flatter someone or tells journalists to twist and distort the truth just because they do not want to lose a benefit. Also, journalists have their ethic; they know what to report and not to report under a standard of conduct of their occupation.

This study demonstrates that there is much agreement between health officials and journalists on the above issues, but that journalists are divided as to how they view the system of journalism. Surprisingly, some government's press thought the idea of government paying was not good and believed the press system was more libertarian than authoritarian. This could be because they are merely comparing it with the way it used to be and relatively speaking, it is more libertarian. This view predominates and makes sense in light of the AIDS research questions. Only one journalist mentioned and 
believed in the social responsibility theory would fit in Thai press system. Under this theory, AIDS/HIV coverage would include more victims of the disease and more perceptions than just health and government. The research reexamining the four theories of the press in the U.S. seems warranted, given the current media environment.

As the Thai press continues to evolve rights, ethics, and more consensuses about its roles in society, its needs, and its responsibilities should emerge. At this critical time, it is wise not to accept government funding, but to abide by their own sense of news values.

One of the limitations of the study is the small number of journalists, and small number of government officials interviewed. Only three TV stations, four newspapers, one radio station were represented, twelve journalists, and six government officials were interviewed. As a result, it is impossible to generalize the results of the study. Also, there's a limitation of access to Thai media in the United States, so I had to contact them overseas by taking note, phone, email, and tape recorder transcription, so there is a possibility of error creeping in during the process. Interviewing with more time, more media outlets, more number of government officials, and more journalists could help increase the study’s validity.

A more detailed study that included interviews with several media organizations, several journalists in Thailand, especially focusing on health reporters and a group of people living with AIDS/HIV, would give a better idea of AIDS reporting and could be compared with the results obtained in this study. This could be a potential future study. 
Another potential future study is to evaluate AIDS campaigns or events that journalists have covered or Thai government has conducted. This would give an idea of how well journalists or Thai government communicate with the public on these issues. 


\section{BIBLIOGRAPHY}

Airhihenbuwa, C. O., \& Obregon, R. (2000). A Critical Assessment of Theories/Models Used in Health Communication for HIV/AIDS. Journal of Health Communication, 5(3), 5-15.

Bardhan, N. (2001). Transnational AIDS-HIV News Narratives: A Critical Exploration of Overarching Frames. Mass Communication \& Society, 4(3), 283-309.

Beaudoin, C. (2005). The Influence of Cultural Values in the Frame-Building Process: A Multinational Study of HIV/AIDS News Coverage. International Communication Association, 1-27.

Brodie, M., Hamel, E., Brady, L.A., Kates, J. \& Altman,D. E. (2004). AIDS at 21: Media coverage of the HIV epidemic 1981-2002. Columbia Journalism Review, March/April.

Brown, J, D., Bybee, C., Wearden, S. \& Staughan D. M. (1987). Invisible power: newspaper news sources and the limits of diversity. Journalism Quarterly, 63, 45-54.

Cassidy, W. P. (2000). The politicizing of AIDS. Newspaper Research Journal, 21(1), 26-39.

Clements, A. (1992). Reprieve for Thailand's AIDS campaign. BMJ: British Medical Journal, 305(6847), 211.

Code of ethics of the journalists association of Thailand. Retrieved October 13, 2006, from http://www.media-accountability.org/html/frameset.php?page=library2

Code of ethics of the press council. (1998). Thailand - Press Council Code, Retrieved October 13, 2006, from http://www.media-

accountability.org/library/Thailand_Journalists_ass.doc

External review of the health sector response to HIV/AIDS in Thailand. (2005).

Executive Summary, 3.

Ford, N. (2004). The role of civil society in protecting public health over commercial interest: lessons from Thailand. The Lancet, 363.

Gans, H. (1979). Deciding what's news: A Study of CBS Evening New, NBC Nightly News, Newsweek and Time. New York: Pantheon Books.

Garbo J. (2000). Southeast Asia's urgent call for HIV prevention. Gayhealth, 15. 
Gilberg, S., Eval, C., McCombs, M., \& Nichols, D. (1980). The state of the union address and the press agenda. Journalism Quarterly, 57, 584-588.

Grabin, F. (1995). HIV update. Cortlandt Forum, 8 (10), 62.

Hanenberg R.S., Rojanapithayakorn W., Kunasol P., \& Sokal D.C.(1994). Impact of Thailand HIV-control programme as indicated by the decline of sexually transmitted diseases. The Lancet, 344, 243-245.

Henry, K. (2005). The Evolution of HIV/AIDS Policy in Thailand 1984-1994. AIDSCAP's Policy Unit as Policy Working, 5.

Human Rights Watch. (2004). Not enough graves: the war on drugs HIV/AIDS and violations of human rights.16 (8).

International Herald Tribune. (2007). Swiss man jailed for 10 years defacing Thai king's image.

International Herald Tribune. (2005). Thailand faces new AIDS threat.

IRINnews. (2006). Increased HIV/AIDS awareness needed - UNAIDS.

Kanshana S., \& Simonds R.J. (2002). National program for preventing mother-child HIV transmission in Thailand: successful implementation and lessons learned. AIDS, 16, 953-959.

Lang, G. E. \& Lang. K. (1983). The battle for public opinion: The president, the press, and the polls during Watergate. New York: Columbia University Press.

Lim, K. (1995). Reporting AIDS: News representations in the Malaysian newspapers. The Journal of Development Communication, 6(1), 79-86.

Lule, J. (2005). AIDS and the News Media: 1980-2005. Critical Studies in Media Communication, 22(3), 256-257.

Medicines Sans Frontiers press release. (2006). US-Thailand Free Trade Agreement: MSF Calls on Thailand to Protect Access to Medicines in the Face of US Pressure.

Mccargo, D. (2002). Politics and the Press in Thailand: Media Machinations. Journal of Southeast Asia Studies, 33(1), 31-105.

Morse, A. (2002). 20 years and still fighting. Retrieved October 13, 2006, from http://www.abcnews.com 
Nath, B. (2006). A gendered response to HIV/AIDS in South Asia and the Pacific: insights from the pandemic in Africa. Gender \& Development, 14(1), 11-22.

Oxfam briefing paper. (2006). Public health at risk: A US free trade agreement could threaten access to medicines in Thailand.

Panos Institute. (2005). Reporting AIDS. An analysis of media environments in Southern Africa.

Phanuphak, P., Locharernkul, C., Panmuong, W., \& Wilde, H. (1985). A report of three cases of AIDS in Thailand. Asian Pac J Allergy Immunol, 3, 195-199.

Pollard, R., \& Walters, E. (2006). IFJ media and research report on the media. HIV/AIDS media guide. 4.

Porapakkham, Y., Pramarnpol, S., et al. (1995). The Evolution of HIV/AIDS Policy in Thailand: 1984-1994.

Pothisiri, P., et al. (1998). Funding priorities for HIV/AIDS crisis in Thailand. 12th World AIDS Conference, Geneva, Switzerland, June.

Internews. (2006). Retrieved February 6,2007, from http://www.internews.org

Shaffer, N., et al. (1999). Short-course zidovudine for perinatal HIV-1 transmission in Bangkok, Thailand: a randomized controlled trial. The Lancet, 353(March 6).

Shoemaker, P.J. \& Reese, S. D. (1996). Mediating the message: Theories of influences on mass media content. New York: Longman.

Siebert, F. S., Theodore P., \& Wilbur, S. (1963). Four Theories of the Press. Urbana: University of Illinois Press.

Sigal, L. (1973). Reporters and officials: The organization and politics of newsmaking. Lexington, MA: D.C. Health and Company.

Siriyuvasak, U. (2002). Thailand media profile 2002. Retrieved February 2,2007, from http://www.freedom.commarts.chula.ac.th/articles/FXSU02Thailand_media_profile_2002.pdf

Soloski, J. (1989). Sources and channels of local news. Journalism Quarterly, 66, 864870.

Stempel III, G. H. \& Culbertson, H. (1984). The prominence and dominance of news sources in newspaper medical coverage. Journalism Quarterly, 6(3), 671-676.

The Nation. (2006). Anti-AIDS campaign to focus on gay men. 
The Nation. (2006). HIV prevention forgotten now verging on crisis.

UNAIDS. (2004). The media and HIV/AIDS: Making a difference. Global Media AIDS Initiative.

UNAIDS. (2006). Report on the Global AIDS Epidemic.

UNDP. (2004). Thailand's Response to HIV/AIDS.

Walters, T.N., Walters, L.M., \& Roger, G. (1996). Agenda Building in the 1992 Presidential Campaign. Public Relations Review, 22(1), 9-24.

Walters. L.M. \& Walters, T.N. (1996). Life on the edge of the precipice: Information subsidy and the rise of AIDS as public issue 1983-1989. Paper presented at the Association for Education in Journalism and Mass Communication Convention, Anaheim, CA:

USAID. (2005). USAID's HIV/AIDS program in Thailand.

UNAIDS/WHO. (2006). Progress on Global Access to HIV Antiretroviral Therapy.

WHO. (1995). 1992-1993 Progress Report Global programme on AIDS Geneva.

World Bank. (1997). Confronting AIDS: public priorities in a global epidemic. Oxford University Press, 276.

World Bank. (2000). Thailand's Response to AIDS: Building on Success. Confronting the Future Thailand social Monitor, V, 10-11. 


\section{APPENDIX A}

There are three groups of interviewees as follows:

1) Government controlled journalists

2) Independent journalists

3) Ministry of Public Health’s officials

1) Do you believe that accepting money from the Thai government to reporting on HIV/AIDS would have a positive or negative impact on the future of a Thai press and the prevalence of HIV?

2) Do you as a member of the Ministry of Public Health believe that giving money to the Thai press will help quell the spread of AIDS faster than allowing voluntary reporting of the disease? Why or why not?

3) Which of the four theories of the press - authoritarian, libertarian, social responsibility, or communist concepts - do you believe Thai journalists, in general, most embrace today? Do you support the information strategy? Why or why not?

4) How would you report on the spread of HIV/AIDS if they were not under government control? And how often?

5) What are your moral/ethical limitations to report on the death of AIDS victims?

6) Do you as a Thai journalist ever feel personally pressured or intimidated by anyone or any agency of the government to either report a story or to not report a story?

7) In your opinion, which is better for the country: control of the press by the government or freedom of the press? 
8) Do you as a member of the Ministry of Public Health see any drawbacks to paying journalists to publish stories about AIDS?

9) Will the Ministry supply the stories as they want them to appear or will journalists cover the stories on their own terms?

10) What does the Ministry propose to do? 


\section{APPENDIX B}

\section{THAILAND}

Conducted by Thailand Media Profile 2002

$\underline{\text { Mass Media }}$

1. Print Media

(a) Newspapers Organizations

$\begin{array}{lc}\text { Type of Organization } & \text { Number } \\ \text { Professional Association } & 15 \\ \text { Private commercial newspaper } & 80 \\ \text { National Newspapers } & 25 \\ \text { Thai } & 20 \\ \text { English } & 2 \\ \text { Chinese } & 2 \\ \text { Muslim } & 1\end{array}$

Source: Public Relations Department

(b) Employment in Newspaper Organizations

Number of Employees

$\begin{array}{lccccc}\text { Names of Organization } & \text { Admin } & \text { Journal } & \text { Prod. } & \text { Others } & \text { Total } \\ \text { Thai Rath } & 50 & 250 & 700 & 650 & 1,650 \\ \text { Daily News } & 30 & 200 & 320 & 200 & 750 \\ \text { Khao Sod } & 20 & 130 & 120 & 100 & 370 \\ \text { Matichon } & 20 & 150 & 135 & 120 & 425 \\ \text { Athit Wikroa } & 20 & 80 & 80 & 70 & 250\end{array}$




$\begin{array}{lccccc}\text { Naew Na } & 30 & 50 & 70 & 100 & 250 \\ \text { Bangkok Post } & 15 & 120 & 298 & 220 & 653 \\ \begin{array}{l}\text { The Nation } \\ \text { Total }\end{array} & 210 & 260 & 246 & 180 & 711 \\ & \\ \begin{array}{l}\text { Source: The Reporters and Newspapers } \\ \text { newspaper }\end{array} & \text { Association of Thailand, } 2000 \text { and the above } \\ \text { (c) Circulation }\end{array}$

(i) Dailies

$\begin{array}{lcc}\text { Daily } & \text { Language } & \text { Circulation } \\ \text { Thai Rath } & \text { Thai } & 800,000 \\ \text { Daily News } & \text { Thai } & 600,000 \\ \text { Khao Sod } & \text { Thai } & 400,000 \\ \text { Kom Chad Luek } & \text { Thai } & 200,000 \\ \text { Matichon } & \text { Thai } & 300,000 \\ \text { Athit Wikroa } & \text { Thai } & 100,000 \\ \text { Naew Na } & \text { Thai } & 100,000 \\ \text { Siam Rath } & \text { Thai } & 80,000 \\ \text { Thai Post } & \text { Thai } & 30,000 \\ \text { Bangkok Post } & \text { Eng } & 65,000 \\ \text { The Nation } & \text { Eng } & 54,060 \\ \text { Total } & & 2,729,060\end{array}$

(ii) Non- Dailies

Non- Daily

Language

Circulation

Matichon Weekly

Thai

80,000 


$\begin{array}{llr}\text { Nation Sudsubda } & \text { Thai } & 30,000 \\ \text { Than Settakit Business Newspaper } & \text { Thai } & 30,000 \\ \text { Siam Rath Weekly } & \text { Thai } & 20,000 \\ \text { Prachachart Turakit } & \text { Thai } & 50,000 \\ \text { Phujadkarn Weekly } & \text { Thai } & 20,000 \\ \text { Total } & & 230,000\end{array}$

(d) Newsprint Consumption

Annual Newsprint Consumption

300,000 ton

Consumption Per 1,000 Population

$5.2 \mathrm{~kg}$.

Print matter import

7,422 ton

(e) Books

Books

Production (No. of Titles

Consumption of books, Newspapers and Magazines
Number

11,000 per year

43,326 Million Bath

(f) News Agencies

(i) Number of Agencies

Type

Local News Agencies

Foreign News Agencies

Foreign Correspondents

Press Associations
Number

7

145

282

15 
(ii) Employment in News Agencies

\begin{tabular}{lccc} 
& & Number of Employees \\
Agency & Journalists & Others & Total \\
Local: & & - & 270 \\
$\quad$ Thai News Agency & 270 & & 11 \\
Foreign: & 6 & 5 & 4 \\
AP & 1 & 3 & 8 \\
AFP & 4 & 4 & 7 \\
NHK & 3 & 4 & 7 \\
Reuters & 3 & 4 & 37 \\
BBC & 21 & 20 & \\
Total & & & \\
\hline
\end{tabular}

(g) Publishers

(i) Number

Publisher Ownership Number

Private 2,000

Total 2,000

Source: Statistics of 1997.

(ii) Name \& Addresses of Publishers \& Association

Top Five Private Publishers: 
1. Ammarine Printing Group, 413/27-36 Arun Ammarine Rd., Pinklow, Bangkok

2. Se-ED Ucation, 800/43-5 Soi Trakoonsook, Asok Din Daeng, Bangkok 10400

3. Matichon, 12 Thetsaban- naruman Rd., Prachanivate 1, BKK 10900

4. Thai Watana Panitch Press, 891, Rama I Road, Patumwan, Bangkok 20330

5. Siam Sports Syndicate, 1776-8 Rama IV Road, Klongtoey, Bangkok

Publishers' Association

1. Publishers and Booksellers Association of Thailand

2. The Federation of Thai Printing Industry

(h) Laws Governing Print Media

Name of Law/Regulation \& Subject/Area Covered

1. The Constitution of Thailand, 1997.

2. The Criminal Code 1956.

3. The Civil and Commercial Code 1924.

4. The Civil Procedure Code 1924.

5. The Press Act 1941.

6. The Act for the Suppression of the Dissemination and Trade in Pornographic Materials 1928.

7. The Copyright Act 1994.

8. The Act to Establish Youth and Family Courts and the Procedure for Youth and Family Cases 1991.

9. Code of Ethics (Journalist Association of Thailand) 1997. 
Source: Vichit Muntabhorn, 1998.

2. Broadcasting Media

(1) Radio

(a) Radio Stations

Radio Stations

Number

Government- owned/Corporation

147

Public Relations Department

3

Military High Command $\quad 14$

$\begin{array}{ll}\text { Army } & 127\end{array}$

$\begin{array}{lr}\text { Navy } & 21\end{array}$

Air Force $\quad 36$

$\begin{array}{lr}\text { Police } & 44\end{array}$

Mass Communication Organization of Thailand (MCOT) 62

$\begin{array}{ll}\text { Parliament } & 16\end{array}$

Ministry of University Affairs $\quad 12$

$\begin{array}{ll}\text { Post and Telegraph Department } & 12\end{array}$

$\begin{array}{ll}\text { Others } & 30\end{array}$

$\begin{array}{ll}\text { Total } & 524\end{array}$

Source: Public Relations Department, 2000.

(b) Employment in Radio Broadcasting Media

State $\quad 1,500$ (including Radio Thailand and regional networks, the Mass Communication Organization of Thailand, Military and other State radio). 
Private $\quad 3,000$ (including independent DJs, major radio news agencies and radio production houses)

(c) Radio Households

$\begin{array}{lcc}\text { Region } & \text { Number } & \text { (\%) } \\ \text { Bangkok } & 1,515.9 & 12.54 \\ \text { Central } & 3,183.2 & 26.34 \\ \text { Northern } & 2,420.5 & 20.03 \\ \text { Northeastern } & 3,532.8 & 29.23 \\ \text { Southern } & 1,433.3 & 11.86\end{array}$

Source: National Statistical Office, Office Attached to the Office of the Prime Minister

(d) Programs

(i) Program Source and Language

Program Source

Local programs

Imported Programs
Language

Thai

English

English

(iia) Top Radio News Production Houses

1. Pacific Communication Ltd., : $15^{\text {th }}$ Floor, 555 Unity Tower, Soi Udomssok, Sukhmvit 103, Bangna, Phrakanong, BKK 10260

2. Nation Radio : 44 Moo10, Bangna- Trad Km. 4.5 Prkhanong BKK 10320

3. INN : Sino-Brit Bldg., Wiphawadi Rangsit, Bangkok

4. GNN : Chang Bldg., Chatuchak, Bangkok 
(iib) Top Radio Enterment Production Houses

1. A Time Media : 21/F1 CMIC Tower B, 209/1 Sukhumvit 21, Klongtoey Naue, BKK 10110

2. R.S. Promotion 1992, 419/1 Chetchotisak Bldg, Ladprao 15, Soi Jompol Chatuchak, BKK 10900

3. BEC World, 2/F1 Vanij 2 Bldg, 1126/2 New Petchburi Makkasan Rajthevi, BKK 10400

(f) External Transmission

(i) Languages of Eternal Transmission

Japanese, Cantonese, French, Cambodia, Vietnamese, Burmese, Malay, Laos.

(g) Foreign Input

None

(h) Annual Budget

4,500 million Baht (1999) or US\$ 118.42 million

(i) Laws Governing Radio Broadcasting Media

1. The Broadcasting Act 1995. 
2. The Radio Communications Act 1995.

3. The Copyright Act 1994.

4. The Official Information Act 1997.

5. Frequencies Regulation Act 2000.

Source: Vichit Muntabhorn, 1998.

(2) Television

(a) Television Stations

Television Station *

Number

$\%$

Government-owned/Corporation \& operation 3

42.8

(Channel 5, 9, 11)

Private Stations (ITV) (state concessions)

3

(Channel 3, 7, ITV)

Others (subscription TV)

1

14.4

(UBC)

Total

*National Station

(b) Employment in Television Broadcasting

\begin{tabular}{lllllll} 
& & & \multicolumn{3}{c}{ Number of Employees } \\
Station & Tech. & Admin. & Journal & Prod. & Other & Total \\
TV3 & 290 & 18 & 185 & 120 & 375 & 988 \\
TV5 & 360 & 20 & 200 & 134 & 386 & 1,100 \\
TV7 & 356 & 17 & 230 & 143 & 328 & 1,074 \\
TV9* & 373 & 28 & 220 & 152 & 315 & 1,088
\end{tabular}




\begin{tabular}{|c|c|c|c|c|c|c|c|}
\hline TV11 & 30 & 12 & 15 & 27 & 104 & & 188 \\
\hline ITV & N/A & N/A & N/A & N/A & N/A & & N/A \\
\hline UBC & N/A & N/A & N/A & N/A & N/A & & N/A \\
\hline *Includ & MCC & $\Gamma$ radic & Tha & sency & & & \\
\hline (c) & levisic & Recei & & & & & \\
\hline Region & & & Nun & & & $\%$ & \\
\hline Bangko & & & 1,62 & & & 11.33 & \\
\hline Central & & & 3,59 & & & 25.08 & \\
\hline Norther & & & 2,81 & & & 19.61 & \\
\hline Northe & & & 4,56 & & & 31.82 & \\
\hline Souther & & & 1,74 & & & 12.16 & \\
\hline Total & & & 14,3 & & & 100 & \\
\hline
\end{tabular}

Source: National Statistical Office, Office of the Prime Minister

(d) TV Programs

(i) Program Type

$\begin{array}{llccccl}\text { Program Type } & \text { Ch3 } & \text { Ch5 } & \text { Ch7 } & \text { Ch9 } & \text { Ch11 } & \text { ITV } \\ & \% & \% & \% & \% & \% & \% \\ \text { News } & 13.06 & 17.96 & 14.37 & 22.3 & 54.01 & 37.67 \\ \text { Documentary } & 4.19 & 11.46 & 4.98 & 20.02 & 29.39 & 15.89 \\ \text { Agriculture } & - & 2.41 & - & 2.72 & 1.91 & 2.38 \\ \text { Religion } & - & 1.31 & 0.29 & 4.07 & 4.55 & 1.2 \\ \text { Travel } & 0.37 & 1.75 & 0.74 & 3.74 & 1.12 & 3.12 \\ \text { Other } & 3.82 & 5.99 & 3.96 & 9.51 & 21.82 & 9.19\end{array}$




$\begin{array}{llllllll}\text { Children } & 7.37 & 0.33 & 5.11 & 9.68 & 1.65 & 3 \\ \text { Education } & 0.91 & - & - & - & 7.71 & - \\ \text { Entertainment } & 74.47 & 70.25 & 75.54 & 47.99 & 7.25 & 43.44 \\ \text { Music } & 3.41 & 16.56 & 8.32 & 17.66 & 3.89 & 8.02 \\ \text { Sport } & 3.71 & 1.62 & 9.24 & 11.21 & 2.96 & 3.14 \\ \text { Drama } & 37.16 & 6.48 & 38.6 & 0.68 & - & 9.05 \\ \text { Comedy } & 1.52 & 6.3 & 0.63 & 0.68 & - & 0.5 \\ \text { Game Show } & 12.36 & 9.44 & 4.33 & 5.83 & 0.4 & 4 \\ \text { Other } & 16.31 & 29.85 & 14.42 & 11.94 & - & 18.74\end{array}$

Source: TV programs schedules, July 2002.

(ii) Languages of Broadcast

$\begin{array}{llc}\text { Name of Station } & \text { Language } & \text { Hrs. / Month } \\ \text { TV3 } & \text { Thai } & 630 \\ \text { TV5 } & \text { Thai } & 720 \\ \text { TV7 } & \text { Thai } & 630 \\ \text { TV9 } & \text { Thai } & 630 \\ \text { TV11 } & \text { Thai } & 600 \\ \text { ITV } & \text { Thai } & 720\end{array}$

UBC (Cable TV 27 Channels) Thai, English, French, Japanese 19,440

Source: TV Programs Schedules, 2002 / UBC Magazine

(iii) Program Source

$\begin{array}{lll}\text { Station } & \text { Local Program } & \text { Import Program Country } \\ & \text { (Hrs. /Month) } & \text { (Hrs. / Month) }\end{array}$




\begin{tabular}{lccl} 
Channel 3 & 474 & 156 & USA, JP, HK, China \\
Channel 5 & 710 & 10 & Eng, China \\
Channel 7 & 478 & 152 & USA, HK, JP, China \\
Channel 9 & 530 & 100 & USA, Eng, JP \\
Channel 11 & 584 & 16 & USA, Eng \\
ITV & 610 & 110 & USA,Eng, HK,JP, Korea \\
UBC & 2,880 & 16,560 & USA, Eng, JP, HK \\
\hline
\end{tabular}

(f) External Transmission

(i) Destination and Language

None

(ii) Type of Programs

None

(g) Foreign Inputs

(i) Foreign Exports

None

(ii) Foreign Experts in Training

None

(iii) Foreign Leased Broadcast

None

(iv) Foreign Programs

Station

Program Type (Hrs. / Month)

Entertainment Sport Documentary News




\begin{tabular}{lllll} 
Channel 3 & 148 & - & 8 & - \\
Channel 5 & 6 & - & 4 & - \\
Channel 7 & 84 & 55 & 13 & - \\
Channel 9 & 27 & 59 & 14 & - \\
Channel 11 & - & 6 & 10 & - \\
ITV & 91 & 5 & 14 & - \\
UBC & 8,640 & 2,880 & 2,880 & 2,160 \\
& $(12 \mathrm{Ch})$ & $(4 \mathrm{Ch})$ & $(4 \mathrm{Ch})$ & $(3 \mathrm{Ch})$ \\
\hline
\end{tabular}

Source: TV Program Schedule, 2002.

(g) Laws Governing TV Broadcasting Media

1. The Broadcasting Act 1955.

2. The Radio Communications Act 1955

3. The Copyright Act 1994.

4. The Act to Establish Youth and Family Courts and the Procedure for Youth and Family Cases 1991.

5. The Official Information Act 1997.

6. Frequencies Regulation Act 2000.

Source: Vichit Muntabhorn, 1998.

(h) Transnationalization of TV Broadcasting

(i) TV Satellite Transmission Received

$\begin{array}{lll}\text { Country } & \text { Source } & \text { Language } \\ \text { Hong Kong } & \text { Star TV } & \text { English } \\ \text { Japan } & \text { NHK } & \text { Japanese }\end{array}$


Australia

USA

English
$\mathrm{ABC}$

CNBC, CNN, NBC English

BBC

English 